4

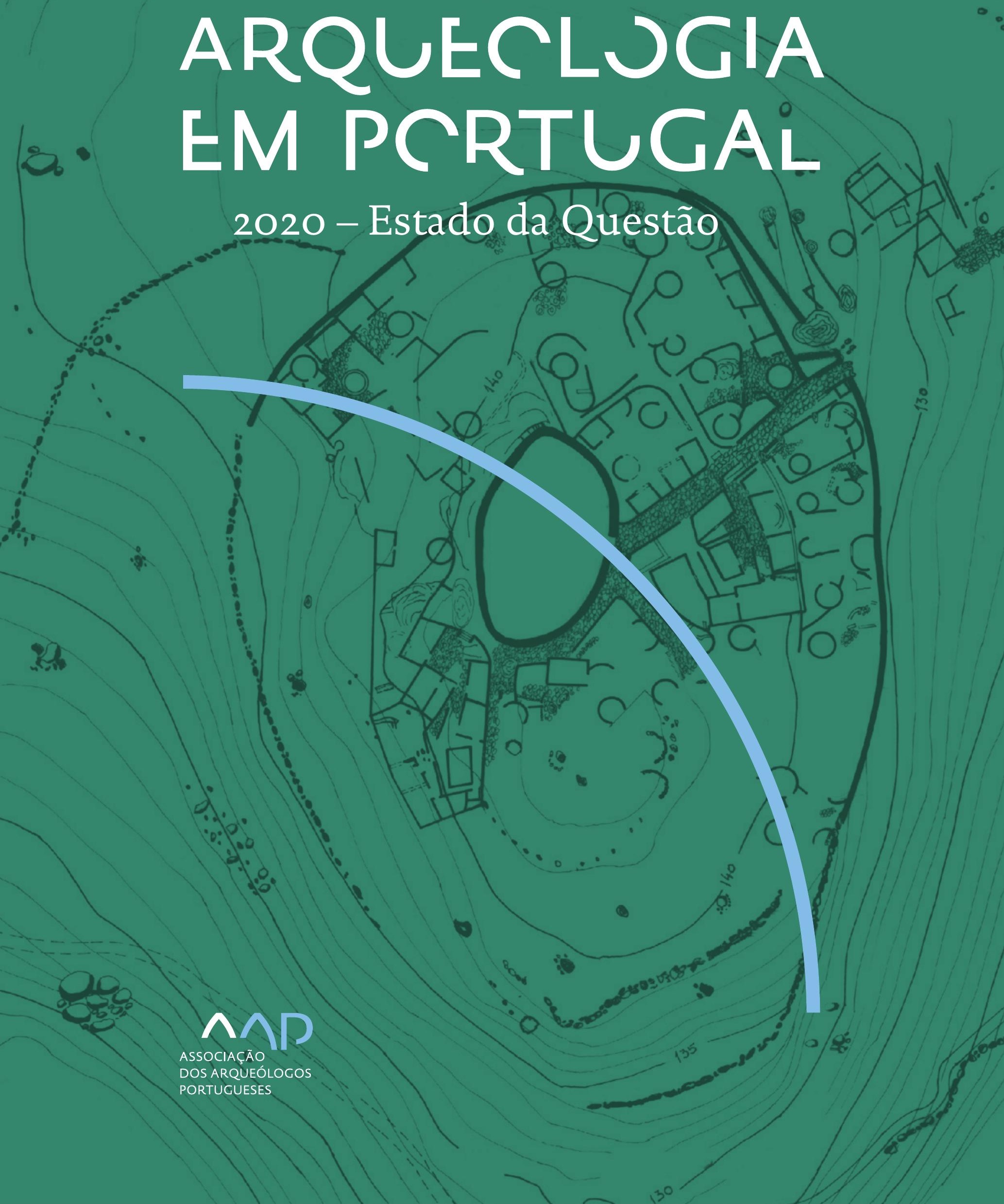


Coordenação editorial: José Morais Arnaud, César Neves e Andrea Martins Design gráfico: Flatland Design

AAP - ISBN: 978-972-9451-89-8

CITCEM - ISBN: 978-989-8970-25-1

Associação dos Arqueólogos Portugueses e CITCEM

Lisboa, 2020

O conteúdo dos artigos é da inteira responsabilidade dos autores. Sendo assim a Associação dos Arqueólogos Portugueses declina qualquer responsabilidade por eventuais equívocos ou questões de ordem ética e legal.

Desenho de capa:

Planta do castro de Monte Mozinho (Museu Municipal de Penafiel).

\section{$\hat{\wedge} \mathrm{P}$}

DOS ARQUEÓLOGOS PORTUGUESES

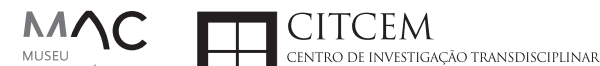
MUSEU
ARQUELLÓGICO
DO CARMO
U.PORTO

FLUP FACULDADE DE LETRAS
UNIVERSIDADE DO PORTO

Apoio

EC para a Ciência 


\section{Índice}

15 Prefácio

José Morais Arnaud

\section{Historiografia e Teoria}

17 Território, comunidade, memória e emoção: a contribuição da história da arqueologia (algumas primeiras e breves reflexões)

Ana Cristina Martins

25 Como descolonizar a arqueologia portuguesa?

Rui Gomes Coelho

41 Arqueologia e Modernidade: uma revisitação pessoal e breve de alguns aspetos da obra homónima de Julian Thomas de 2004

Vítor Oliveira Jorge

57 Dados para a História das Mulheres na Arqueologia portuguesa, dos finais do século XIX aos inícios do século XX: números, nomes e tabelas

Filipa Dimas / Mariana Diniz

73 Retractos da arqueologia portuguesa na imprensa: (in)visibilidades no feminino

Catarina Costeira / Elsa Luís

85 Arqueologia e Arqueólogos no Norte de Portugal Jacinta Bugalhão

101 Vieira Guimarães (1864-1939) e a arqueologia em Tomar: uma abordagem sobre o território e as gentes

João Amendoeira Peixoto / Ana Cristina Martins

115 Os memoráveis? A arqueologia algarvia na imprensa nacional e regional na presente centúria (2001-2019): características, visões do(s) passado(s) e a arqueologia

enquanto marca

Frederico Agosto / João Silva

129 A Evolução da Arqueologia Urbana e a Valorização Patrimonial no Barlavento Algarvio: Os casos de Portimão e Silves

Artur Mateus / Diogo Varandas / Rafael Boavida

\section{Gestão, Valorização e Salvaguarda do Património}

145 O Caderno Reivindicativo e as condições de trabalho em Arqueologia Miguel Rocha / Liliana Matias Carvalho / Regis Barbosa / Mauro Correia / Sara Simões / Jacinta Bugalhão / Sara Brito / Liliana Veríssimo Carvalho / Richard Peace / Pedro Peça / Cézer Santos

155 Os Estudos de Impacte Patrimonial como elemento para uma estratégia sustentável de minimização de impactes no âmbito de reconversões agrícolas Tiago do Pereiro

165 Salvaguarda de Património arqueológico em operações florestais: gestão e sensibilização Filipa Bragança / Gertrudes Zambujo / Sandra Lourenço / Belém Paiva / Carlos Banha / Frederico Tatá Regala / Helena Moura / Jacinta Bugalhão / João Marques / José Correia / Pedro Faria / Samuel Melro

179 Os valores do Património: uma investigação sobre os Sítios Pré-históricos de Arte Rupestre do Vale do Rio Côa e de Siega Verde José Paulo Francisco 
189 Conjugando recursos arqueológicos e naturais para potenciar as visitas ao Geoparque Litoral de Viana do Castelo (Noroeste de Portugal)

Hugo A. Sampaio / Ana M.S. Bettencourt / Susana Marinho / Ricardo Carvalhido

203 Áreas de Potencial Arqueológico na Região do Médio Tejo: Modelo Espacial Preditivo Rita Ferreira Anastácio / Ana Filipa Martins / Luiz Oosterbeek

223 Património Arqueológico e Gestão Territorial: O contributo da Arqueologia para a revisão do PDM de Avis

Ana Cristina Ribeiro

237 A coleção arqueológica do extinto Museu Municipal do Porto - Origens, Percursos e Estudos

Sónia Couto

251 Valpaços - uma nova carta arqueológica

Pedro Pereira / Maria de Fátima Casares Machado

263 Arqueologia na Cidade de Peniche

Adriano Constantino / Luís Rendeiro

273 Arqueologia Urbana: a cidade de Lagos como caso de Estudo Cátia Neto

285 Estratégias de promoção do património cultural subaquático nos Açores. O caso da ilha do Faial

José Luís Neto / José Bettencourt / Luís Borges / Pedro Parreira

297 Carta Arqueológica da Cidade Velha: Uma primeira abordagem

Jaylson Monteiro / Nireide Tavares / Sara da Veiga / Claudino Ramos / Edson Brito /

Carlos Carvalho / Francisco Moreira / Adalberto Tavares

311 Antropologia Virtual: novas metodologias para a análise morfológica e funcional Ricardo Miguel Godinho / Célia Gonçalves

\section{Didáctica da Arqueologia}

327 Como os projetos de Arqueologia podem contribuir para uma comunidade culturalmente mais consciente Alexandra Figueiredo / Claúdio Monteiro / Adolfo Silveira / Ricardo Lopes

337 Educação Patrimonial - Um cidadão esclarecido é um cidadão ativo! Ana Paula Almeida

351 A aproximação da Arqueologia à sala de aula: um caso de estudo no $3^{\circ}$ ciclo do Ensino Básico Luís Serrão Gil

363 Arqueologia 3.o - Pensar e comunicar a Arqueologia para um futuro sustentável Mónica Rolo

377 “Conversa de Arqueólogos" - Divulgar a Arqueologia em tempos de Pandemia Diogo Teixeira Dias

389 Escola Profissional de Arqueologia: desafios e oportunidades Susana Nunes / Dulcineia Pinto / Júlia Silva / Ana Mascarenhas

399 Os Museus de Arqueologia e os Jovens: a oferta educativa para o público adolescente Beatriz Correia Barata / Leonor Medeiros

411 O museu universitário como mediador entre a ciência e a sociedade: o exemplo da secção de arqueologia no Museu de História Natural e da Ciência da Universidade do Porto (MHNC-UP)

Rita Gaspar 
421 Museu de Lanifícios: Real Fábrica de Panos. Atividades no âmbito da Arqueologia Beatriz Correia Barata / Rita Salvado

427 Arqueologia Pública e o caso da localidade da Mata (Torres Novas) Cláudia Manso / Ana Rita Ferreira / Cristiana Ferreira / Vanessa Cardoso Antunes

431 Do sítio arqueológico ao museu: um percurso (também) didático Lídia Fernandes

447 Estão todos convidados para a Festa! E para dançar também... O projecto do Serviço Educativo do Museu Arqueológico do Carmo na $5^{\underline{a}}$ Edição da Festa da Arqueologia Rita Pires dos Santos

459 O “Clã de Carenque”, um projeto didático de arqueologia Eduardo Gonzalez Rocha

469 Mediação cultural: peixe que puxa carroça nas Ruínas Romanas de Troia Inês Vaz Pinto / Ana Patrícia Magalhães / Patrícia Brum / Filipa Santos

481 Didática Arqueológica, experiências do Projeto Mértola Vila Museu Maria de Fátima Palma / Clara Rodrigues / Susana Gómez / Lígia Rafael

\section{Arte Rupestre}

497 Os inventários de arte rupestre em Portugal Mila Simões de Abreu

513 O projeto FIRST-ART - conservação, documentação e gestão das primeiras manifestações de arte rupestre no Sudoeste da Península Ibérica: as grutas do Escoural e Maltravieso Sara Garcês / Hipólito Collado / José Julio García Arranz / Luiz Oosterbeek / António Carlos Silva / Pierluigi Rosina / Hugo Gomes / Anabela Borralheiro Pereira / George Nash / Esmeralda Gomes / Nelson Almeida / Carlos Carpetudo

523 Trabalhos de documentação de arte paleolítica realizados no âmbito do projeto PalæoCôa André Tomás Santos / António Fernando Barbosa / Luís Luís / Marcelo Silvestre / Thierry Aubry

537 Imagens fantasmagóricas, silhuetas elusivas: as figuras humanas na arte do Paleolítico Superior da região do Côa Mário Reis

$55^{1}$ Os motivos zoomórficos representados nas placas de tear de Vila Nova de São Pedro (Azambuja, Portugal) Andrea Martins / César Neves / José M. Arnaud / Mariana Diniz

571 Arte Rupestre do Monte de Góios (Lanhelas, Caminha). Síntese dos resultados dos trabalhos efectuados em 2007-2009 Mário Varela Gomes

599 Gravuras rupestres de barquiformes no Monte de S. Romão, Guimarães, Noroeste de Portugal Daniela Cardoso

613 Círculos segmentados gravados na Bacia do Rio Lima (Noroeste de Portugal): contributos para o seu estudo Diogo Marinho / Ana M.S. Bettencourt / Hugo Aluai Sampaio

631 Equídeos gravados no curso inferior do Rio Mouro, Monção (NW Portugal). Análise preliminar Coutinho, L.M. / Bettencourt, A.M.S / Sampaio, Hugo A.S

645 Paletas na Arte Rupestre do Noroeste de Portugal. Inventário preliminar Bruna Sousa Afonso / Ana M. S. Bettencourt / Hugo A. Sampaio 


\section{Pré-História}

661 O projeto Miño/Minho: balanço de quatro anos de trabalhos arqueológicos Sérgio Monteiro-Rodrigues / João Pedro Cunha-Ribeiro / Eduardo Méndez-Quintas / Carlos Ferreira / Pedro Xavier / José Meireles / Alberto Gomes / Manuel Santonja / Alfredo Pérez-González

677 A ocupação paleolítica da margem esquerda do Baixo Minho: a indústria lítica do sítio de Pedreiras 2 (Monção, Portugal) e a sua integração no contexto regional Carlos Ferreira / João Pedro Cunha-Ribeiro / Sérgio Monteiro-Rodrigues / Eduardo Méndez-Quintas / Pedro Xavier / José Meireles / Alberto Gomes / Manuel Santonja / Alfredo Pérez-González

693 O sítio acheulense do Plistocénico médio da Gruta da Aroeira Joan Daura / Montserrat Sanz / Filipa Rodrigues / Pedro Souto / João Zilhão

703 As sociedades neandertais no Barlavento algarvio: modelos preditivos com recurso aos SIG

Daniela Maio

715 A utilização de quartzo durante o Paleolítico Superior no território dos vales dos rios Vouga e Côa

Cristina Gameiro / Thierry Aubry / Bárbara Costa / Sérgio Gomes / Luís Luís / Carmen Manzano / André Tomás Santos

733 Uma perspetiva diacrónica da ocupação do concheiro do Cabeço da Amoreira (Muge, Portugal) a partir da tecnologia lítica Joana Belmiro / João Cascalheira / Célia Gonçalves

745 Novos dados sobre a Pré-história Antiga no concelho de Palmela. A intervenção arqueológica no sítio do Poceirão I

Michelle Teixeira Santos

757 Problemas em torno de Datas Absolutas Pré-Históricas no Norte do Alentejo Jorge de Oliveira

771 Povoamento pré-histórico nas áreas montanhosas do NO de Portugal: o Abrigo 1 de Vale de Cerdeira Pedro Xavier / José Meireles / Carlos Alves

783 Apreciação do povoamento do Neolítico Inicial na Baixa Bacia do Douro. A Lavra I (Serra da Aboboreira) como caso de estudo Maria de Jesus Sanches

797 O Processo de Neolitização na Plataforma do Mondego: os dados do Sector C do Outeiro dos Castelos de Beijós (Carregal do Sal)

João Carlos de Senna-Martinez / José Manuel Quintã Ventura / Andreia Carvalho / Cíntia Maurício

823 Novos trabalhos na Lapa da Bugalheira (Almonda, Torres Novas) Filipa Rodrigues / Pedro Souto / Artur Ferreira / Alexandre Varanda / Luís Gomes / Helena Gomes / João Zilhão

837 A pedra polida e afeiçoada do sítio do Neolítico médio da Moita do Ourives (Benavente, Portugal)

César Neves

857 Casal do Outeiro (Encarnação, Mafra): novos contributos para o conhecimento do povoamento do Neolítico final na Península de Lisboa.

Cátia Delicado / Carlos Maneira e Costa / Marta Miranda / Ana Catarina Sousa

873 Stresse infantil, morbilidade e mortalidade no sítio arqueológico do Neolítico Final/ Calcolítico ( $4^{\circ}$ e $3^{\circ}$ milénio a.C.) do Monte do Carrascal 2 (Ferreira do Alentejo, Beja) Liliana Matias de Carvalho / Sofia N. Wasterlain 
885 Come together: O Conjunto Megalítico das Motas (Monção, Viana do Castelo) e as expressões Campaniformes do Alto Minho Ana Catarina Basílio / Rui Ramos

899 Trabalhos arqueológicos no sítio Calcolítico da Pedreira do Poio Carla Magalhães / João Muralha / Mário Reis / António Batarda Fernandes

913 O sítio arqueológico de Castanheiro do Vento. Da arquitectura do sítio à arquitectura de um território João Muralha Cardoso

925 Estudo zooarqueológico das faunas do Calcolítico final de Vila Nova de São Pedro (Azambuja, Portugal): Campanhas de 2017 e 2018 Cleia Detry / Ana Catarina Francisco / Mariana Diniz / Andrea Martins / César Neves / José Morais Arnaud

943 As faunas depositadas no Museu Arqueológico do Carmo provenientes de Vila Nova de São Pedro (Azambuja): as campanhas de 1937 a 1967 Ana Catarina Francisco / Cleia Detry / César Neves / Andrea Martins / Mariana Diniz / José Morais Arnaud

959 Análise funcional de material lítico em sílex do castro de Vila Nova de S. Pedro (Azambuja, Portugal): uma primeira abordagem Rafael Lima

971 O recinto da Folha do Ouro 1 (Serpa) no contexto dos recintos de fossos calcolíticos alentejanos

António Carlos Valera / Tiago do Pereiro / Pedro Valério / António M. Monge Soares

\section{Proto-História}

987 Produção de sal marinho na Idade do Bronze do noroeste Português. Alguns dados para uma reflexão

Ana M. S. Bettencourt / Sara Luz / Nuno Oliveira / Pedro P. Simões / Maria Isabel C. Alves / Emílio Abad-Vidal

1001 A estátua-menir do Pedrão ou de São Bartolomeu do Mar (Esposende, noroeste de Portugal) no contexto arqueológico da fachada costeira de entre os rios Neiva e Cávado Ana M. S. Bettencourt / Manuel Santos-Estévez / Pedro Pimenta Simões / Luís Gonçalves

1015 O Castro do Muro (Vandoma/Baltar, Paredes) - notas para uma biografia de ocupação da Idade do Bronze à Idade Média

Maria Antónia D. Silva / Ana M. S. Bettencourt / António Manuel S. P. Silva / Natália Félix

1031 Do Bronze Final à Idade Média - continuidades e hiatos na ocupação de Povoados em Oliveira de Azeméis João Tiago Tavares / Adriaan de Man

1041 As faunas do final da Idade do Bronze no Sul de Portugal: leituras desde o Outeiro do Circo (Beja)

Nelson J. Almeida / Íris Dias / Cleia Detry / Eduardo Porfírio / Miguel Serra

1055 A Espada do Monte das Oliveiras (Serpa) - uma arma do Bronze Pleno do Sudoeste Rui M. G. Monge Soares / Pedro Valério / Mariana Nabais / António M. Monge Soares

1065 São Julião da Branca (Albergaria-a-Velha) - Investigação e valorização de um povoado do Bronze Final

António Manuel S. P. Silva / Paulo A. P. Lemos / Sara Almeida e Silva / Edite Martins de Sá

1083 Do castro de S. João ao Mosteiro de Santa Clara: notícia de uma intervenção arqueológica, em Vila do Conde Rui Pinheiro 
1095 O castro de Ovil (Espinho), um quarto de século de investigação - resultados e questões em aberto

Jorge Fernando Salvador / António Manuel S. P. Silva

1111 O Castro de Salreu (Estarreja), um povoado proto-histórico no litoral do Entre Douro e Vouga

Sara Almeida e Silva / António Manuel S. P. Silva / Paulo A. P. Lemos / Edite Martins de Sá

1127 Castro de Nossa Senhora das Necessidades (Sernancelhe): uma primeira análise artefactual Telma Susana O. Ribeiro

${ }_{1141}$ A cividade de Bagunte. O estado atual da investigação Pedro Brochado de Almeida

1153 Zoomorfos na cerâmica da Idade do Ferro no NW Peninsular: inventário, cronologias e significado Nuno Oliveira / Cristina Seoane

1163 Vasos gregos em Portugal: diferentes maneiras de contar a história do intercâmbio cultural na Idade do Ferro

Daniela Ferreira

1175 Os exotica da necrópole da Idade do Ferro do Olival do Senhor dos Mártires (Alcácer do Sal) no seu contexto regional

Francisco B. Gomes

\section{Antiguidade Clássica e Tardia}

1191 O uso de madeira como combustível no sítio da Quinta de Crestelos (Baixo Sabor): da Idade do Ferro à Romanização Filipe Vaz / João Tereso / Sérgio Simões Pereira / José Sastre / Javier Larrazabal Galarza / Susana Cosme / José António Pereira / Israel Espi

1207 Cultivos de Época Romana no Baixo Sabor: continuidade em tempos de mudança? João Pedro Tereso / Sérgio Simões Pereira / Filipe Santos / Luís Seabra / Filipe Vaz

1221 A casa romana na Hispânia: aplicação dos modelos itálicos nas províncias ibéricas Fernanda Magalhães / Diego Machado / Manuela Martins

1235 As pinturas murais romanas da Rua General Sousa Machado, n. ${ }^{5}$ 1, Chaves José Carvalho

1243 Trás do Castelo (Vale de Mir, Pegarinhos, Alijó) - Uma exploração agrícola romana do Douro

Tony Silvino / Pedro Pereira

1255 A sequência de ocupação no quadrante sudeste de Bracara Augusta: as transformações de uma unidade doméstica Lara Fernandes / Manuela Martins

1263 Os Mosaicos com decoração geométrica e geométrico-vegetalista dos sítios arqueológicos da área do Conuentus Bracaraugustanus. Novas abordagens quanto à conservação, restauro, decoração e datação Maria de Fátima Abraços / Licínia Wrench

1277 “Casa Romana” do Castro de São Domingos (Cristelos, Lousada): Escavação, Estudo e Musealização Paulo André de P. Lemos

1291 A arqueobotânica no Castro de Guifões (Matosinhos, Noroeste de Portugal): O primeiro estudo carpológico

Luís Seabra / Andreia Arezes / Catarina Magalhães / José Varela / João Pedro Tereso 
1305 Um Horreum Augustano na Foz do Douro (Monte do Castelo de Gaia, Vila Nova de Gaia) Rui Ramos

1311 Ponderais romanos na Lusitânia: padrões, formas, materiais e contextos de utilização Diego Barrios Rodríguez

1323 Um almofariz centro-itálico na foz do Mondego

Marco Penajoia

1335 Estruturas romanas de Carnide - Lisboa Luísa Batalha / Mário Monteiro / Guilherme Cardoso

1347 O contexto funerário do sector da "necrópole NO" da Rua das Portas de S. Antão (Lisboa): o espaço, os artefactos, os indivíduos e a sua interconectividade na interpretação do passado Sílvia Loja, José Carlos Quaresma, Nelson Cabaço, Marina Lourenço, Sílvia Casimiro, Rodrigo Banha da Silva, Francisca Alves-Cardoso

${ }_{1361}$ Povoamento em época Romana na Amadora - resultados de um projeto pluridisciplinar Gisela Encarnação / Vanessa Dias

1371 A Arquitectura Residencial em Mirobriga (Santiago do Cacém): contributo a partir de um estudo de caso Filipe Sousa / Catarina Felício

${ }_{1385}$ O fim do ciclo. Saneamento e gestão de resíduos nos edifícios termais de Mirobriga (Santiago do Cacém)

Catarina Felício / Filipe Sousa

1399 Balsa, Topografia e Urbanismo de uma Cidade Portuária Vítor Silva Dias / João Pedro Bernardes / Celso Candeias / Cristina Tété Garcia

1413 No Largo das Mouras Velhas em Faro (2017): novas evidências da necrópole norte de Ossonoba e da sua ocupação medieval Ricardo Costeira da Silva / Paulo Botelho / Fernando Santos / Liliana Nunes

1429 Instrumentos de pesca recuperados numa fábrica de salga em Ossonoba (Faro) Inês Rasteiro / Ricardo Costeira da Silva / Paulo Botelho

1439 A Necrópole Romana do Eirô, Duas Igrejas (Penafiel): intervenção arqueológica de 2016 Laura Sousa / Teresa Soeiro

1457 Ritual, descarte ou afetividade? A presença de Canis lupus familiaris na Necrópole Noroeste de Olisipo (Lisboa)

Beatriz Calapez Santos / Sofia Simões Pereira / Rodrigo Banha da Silva / Sílvia Casimiro / Cleia Detry / Francisca Alves Cardoso

1467 Dinâmicas económicas em Bracara na Antiguidade Tardia Diego Machado / Manuela Martins / Fernanda Magalhães / Natália Botica

1479 Cerâmicas e Vidros da Antiguidade Tardia do Edifício sob a Igreja do Bom Jesus (Vila Nova de Gaia) Joaquim Filipe Ramos

1493 Novos contributos para a topografia histórica de Mértola no período romano e na Antiguidade Tardia Virgílio Lopes

\section{8. Época Medieval}

1511 Cerâmicas islâmicas no Garb setentrional "português": algumas evidências e incógnitas Constança dos Santos / Helena Catarino / Susana Gómez / Maria José Gonçalves / Isabel Inácio / Gonçalo Lopes / Jacinta Bugalhão / Sandra Cavaco / Jaquelina Covaneiro / Isabel Cristina Fernandes / Ana Sofia Gomes 
1525 Contributo para o conhecimento da cosmética islâmica, em Silves, durante a Idade Média Rosa Varela Gomes

1537 Yábura e o seu território - uma análise histórico-arqueológica de Évora entre os séculos VIII-XII José Rui Santos

1547 A encosta sul do Castelo de Palmela - resultados preliminares da escavação arqueológica Luís Filipe Pereira / Michelle Teixeira Santos

1559 A igreja de São Lourenço (Mouraria, Lisboa): um conjunto de silos e de cerâmica medieval islâmica

Andreia Filipa Moreira Rodrigues

1571 O registo material de movimentações populacionais no Médio Tejo, durante os séculos XII-XIII. Dois casos de "sunken featured buildings", nos concelhos de Cartaxo e Torres Novas Marco Liberato / Helena Santos / Nuno Santos

1585 O nordeste transmontano nos alvores da Idade média. Notas para reflexão Ana Maria da Costa Oliveira

1601 Sepulturas escavadas na rocha do Norte de Portugal e do Vale do Douro: primeiros resultados do Projecto SER-NPVD

Mário Jorge Barroca / César Guedes / Andreia Arezes / Ana Maria Oliveira

1619 "Portucalem Castrum Novum" entre o Mediterrâneo e o Atlântico: o estudo dos materiais cerâmicos alto-medievais do arqueossítio da rua de D. Hugo, nํ. 5 (Porto) João Luís Veloso

1627 A Alta Idade Média na fronteira de Lafões: notas preliminares sobre a Arqueologia no Concelho de Vouzela

Manuel Luís Real / Catarina Tente

1641 Um conjunto cerâmico medieval fora de portas: um breve testemunho aveirense Susana Temudo

${ }_{1651}$ Os Lóios do Porto: uma perspetiva integrada no panorama funerário da Baixa Idade Média à Época Moderna em meios urbanos em Portugal

Ana Lema Seabra

1659 O Caminho Português Interior de Santiago como eixo viário na Idade Média Pedro Azevedo

1665 Morfologia Urbana: Um exercício em torno do Castelo de Ourém André Donas-Botto / Jaqueline Pereira

1677 Intervenção arqueológica na Rua Marquês de Pombal/Largo do Espírito Santo (Bucelas, Loures)

Florbela Estêvão / Nathalie Antunes-Ferreira / Dário Ramos Neves / Inês Lisboa

1691 O Cemitério Medieval do Poço do Borratém e a espacialidade funerária na cidade de Lisboa Inês Belém / Vanessa Filipe / Vasco Noronha Vieira / Sónia Ferro / Rodrigo Banha da Silva

1705 Um Espaço Funerário Conventual do séc. XV em Lisboa: o caso do Convento de São Domingos da Cidade Sérgio Pedroso / Sílvia Casimiro / Rodrigo Banha da Silva / Francisca Alves Cardoso

\section{9. Época Moderna e Contemporânea}

1721 Arqueologia Moderna em Portugal: algumas reflexões críticas em torno da quantificação de conjuntos cerâmicos e suas inferências históricas e antropológicas Rodrigo Banha da Silva / André Bargão / Sara da Cruz Ferreira

1733 Faianças de dois contextos entre os finais do século XVI e XVIII do Palácio dos Condes de Penafiel, Lisboa

Martim Lopes / Tomás Mesquita 
1747 Um perfil de consumo do século XVIII na foz do Tejo: O caso do Mercado da Ribeira, Lisboa Sara da Cruz Ferreira / Rodrigo Banha da Silva / André Bargão

1761 Os Cachimbos dos Séculos XVII e XVIII do Palácio Mesquitela e Convento dos Inglesinhos (Lisboa)

Inês Simão / Marina Pinto / João Pimenta / Sara da Cruz Ferreira / André Bargão / Rodrigo Banha da Silva

1775 "Tomar os fumos da erua que chamão em Portugal erua sancta». Estudo de Cachimbos provenientes da Rua do Terreiro do Trigo, Lisboa

Miguel Martins de Sousa / José Pedro Henriques / Vanessa Galiza Filipe

1787 Cachimbos de Barro Caulínitico da Sé da Cidade Velha (República de Cabo Verde)

Rodrigo Banha da Silva / João Pimenta / Clementino Amaro

1801 Algumas considerações sobre espólio não cerâmico recuperado no Largo de Jesus (Lisboa) Carlos Boavida

1815 Adereços de vidro, dos séculos XVI-XVIII, procedentes do antigo Convento de Santana de Lisboa (anéis, braceletes e contas)

Joana Gonçalves / Rosa Varela Gomes / Mário Varela Gomes

1837 Da ostentação, luxo e poder à simplicidade do uso quotidiano: arqueologia e simbologia de joias e adornos da Idade Moderna Portuguesa Jéssica Iglésias

1849 Os amuletos em Portugal - dos objetos às superstições: o coral vermelho Alexandra Vieira

1865 Cerâmicas de Vila Franca de Xira nos séculos XV e XVI Eva Pires

1879 «Não passa por teu o que me pertence». Marcas de individualização associadas a faianças do Convento de Nossa Senhora de Aracoeli, Alcácer do Sal Catarina Parreira / Íris Fragoso / Miguel Martins de Sousa

1891 Cerâmica de Leiria: alguns focos de produção

Jaqueline Pereira / André Donas-Botto

1901 Os Fornos na Rua da Biquinha, em Óbidos Hugo Silva / Filipe Oliveira

1909 A casa de Pêro Fernandes, contador dos contos de D. Manuel I: o sítio arqueológico da Silha do Alferes, Seixal (século XVI) Mariana Nunes Ferreira

1921 O Alto da Vigia (Sintra) e a vigilância e defesa da costa Alexandre Gonçalves / Sandra Santos

1937 O contexto da torre sineira da Igreja de Santa Maria de Loures Paulo Calaveira / Martim Lopes

1949 A Necrópole do Hospital Militar do Castelo de São Jorge e as práticas funerárias na Lisboa de Época Moderna Susana Henriques / Liliana Matias de Carvalho / Ana Amarante / Sofia N. Wasterlain

1963 SAND - Sarilhos Grandes Entre dois Mundos: o adro da Igreja e a Paleobiologia dos ossos humanos recuperados

Paula Alves Pereira / Roger Lee Jesus / Bruno M. Magalhães

1975 Expansão urbana da vila de Cascais no século XVII e XVIII: a intervenção arqueológica na Rua da Vitória no 15 a 17

Tiago Pereira / Vanessa Filipe

1987 Novos dados para o conhecimento do Urbanismo de Faro em época Moderna Ana Rosa 
1995 Um exemplo de Arqueologia Urbana em Alcoutim: o Antigo Edifício dos CTT Marco Fernandes / Marta Dias / Alexandra Gradim / Virgílio Lopes / Susana Gómez Martínez

2007 Palácio dos Ferrazes (Rua das Flores/Rua da Vitória, Porto): a cocheira de Domingos Oliveira Maia

Francisco Raimundo

2021 As muitas vidas de um edifício urbano: História, Arqueologia e Antropologia no antigo Recreatório Paroquial de Penafiel Helena Bernardo / Jorge Sampaio / Marta Borges

2035 O convento de Nossa Senhora da Esperança de Ponta Delgada: o contributo da arqueologia para o conhecimento de um monumento identitário João Gonçalves Araújo / N’Zinga Oliveira

2047 Arqueologia na ilha do Corvo... em busca da capela de Nossa Senhora do Rosário Tânia Manuel Casimiro / José Luís Neto / Luís Borges / Pedro Parreira

2059 Perdidos à vista da Costa. Trabalhos arqueológicos subaquáticos na Barra do Tejo Jorge Freire / José Bettencourt / Augusto Salgado

2071 Arqueologia marítima em Cabo Verde: enquadramento e primeiros resultados do projecto CONCHA

José Bettencourt / Adilson Dias / Carlos Lima / Christelle Chouzenoux / Cristóvão Fonseca / Dúnia Pereira / Gonçalo Lopes / Inês Coelho / Jaylson Monteiro / José Lima / Maria Eugénia Alves / Patrícia Carvalho / Tiago Silva

2085 Trabalhos arqueológicos na Cidade Velha (Ribeira Grande de Santiago, Cabo Verde): reflexões sobre um projecto de investigação e divulgação patrimonial André Teixeira / Jaylson Monteiro / Mariana Mateus / Nireide Tavares / Cristovão Fonseca / Gonçalo C. Lopes / Joana Bento Torres / Dúnia Pereira / André Bargão / Aurélie Mayer / Bruno Zélie / Carlos Lima / Christelle Chouzenoux / Inês Henriques / Inês Pinto Coelho / José Lima / Patrícia Carvalho / Tiago Silva

2103 A antiga fortificação de Quelba / Khor Kalba (E.A.U.). Resultados de quatro campanhas de escavações, problemáticas e perspectivas futuras Rui Carita / Rosa Varela Gomes / Mário Varela Gomes / Kamyar Kamyad

2123 Colónias para homens novos: arqueologia da colonização agrária fascista no noroeste ibérico Xurxo Ayán Vila / José Mạ . Señorán Martín 


\title{
OS MOTIVOS ZOOMÓRFICOS \\ REPRESENTADOS NAS PLACAS DE \\ TEAR DE VILA NOVA DE SÃO PEDRO \\ (AZAMBUJA, PORTUGAL)
}

\author{
Andrea Martins ${ }^{1}$, César Neves ${ }^{2}$, José Morais Arnaud ${ }^{3}$, Mariana Diniz ${ }^{4}$
}

\begin{abstract}
RESUMO
Do abundante espólio recolhico nas escavações realizadas entre 1936 e 1967 no povoado calcolítico de Vila Nova de São Pedro destacam-se cerca de 500 elementos em cerâmica comummente designados por "placas de tear" que apresentam distintas tipologias, dimensões e, a maioria, as superfícies decoradas. O dispositivo iconográfico presente nas placas é bastante diversificado, sendo predominantes os motivos geométricos, existindo também motivos soliformes, antropomórficos e zoomórficos. Desta última categoria encontram-se identificados 11 exemplares, no espólio depositado no Museu Arqueológico do Carmo, cuja tipologia se divide em dois tipos: quadrúpedes - cuja espécie não é identificável - e representações de cervídeos.

Estes motivos iconográficos fazem parte do universo simbólico e conceptual das comunidades peninsulares do $3^{\circ}$ milénio a.C., surgindo igualmente em diversas categorias artefactuais tais como cerâmicas, estatuetas, placas, gravuras e pinturas rupestres. Compreender os mecanismos que potenciam esta uniformidade temática, bem como a importância do cervídeo para estes grupos agro-pastoris, permitirá mais uma aproximação ao enquadramento cultural e social destas comunidades.

Palavras-chave: Vila Nova de São Pedro, Placas de tear, Zoomorfos, Cervídeos, Iconografia.
\end{abstract}

\section{ABSTRACT}

From the excavations carried out between 1936 and 1967 in the Chalcolithic settlement of Vila Nova de São Pedro (Azambuja, Portugal), there were recovered more than 500 ceramic elements usually known as "loom weights" with different shapes, dimensions and, in the majority, with decorated surfaces. The iconographic repertoire is quite diverse, with the geometric motifs in higher representation, followed by soliforms, anthropomorphic and zoomorphic motifs. For the zoomorphic motifs there were identified eleven decorated surfaces, whose typology is split into two categories: quadruped - whose species are not identifiable; deer representations.

These iconographic motifs are part of the symbolic and conceptual universe of Iberian communities from the $3^{\text {rd }}$ Millennium BC, also appearing in several artifactual categories such as ceramics, figurines, plates, engravings and rock art paintings. Understanding the mechanisms that create and increase this thematic uniformity, as well as the meaning of the deer for these agro pastoral groups, will allow a closer approach to the cultural and social behavior of these communities.

Keywords: Vila Nova de São Pedro, Loom weights, Zoomorphic figures, Cervids, Iconography.

\footnotetext{
1. Uniarq, Centro de Arqueologia da Faculdade de Letras da Universidade de Lisboa / FCT/ Associação dos Arqueólogos Portugueses; andrea.arte@gmail.com

2.Associação dos Arqueólogos Portugueses / Centro de Arqueologia da Faculdade de Letras da Universidade de Lisboa; c.augustoneves@gmail.com

3. Associação dos Arqueólogos Portugueses; jemarnaud@gmail.com

4. Uniarq, Centro de Arqueologia da Faculdade de Letras da Universidade de Lisboa / FCT/ Associação dos Arqueólogos Portugueses; m.diniz@fl.ul.pt
} 


\section{VILA NOVA DE SÃO PEDRO E AS PLACAS DE TEAR: ÍCONES DESDE A PRIMEIRA HORA}

Escrever sobre o espólio de Vila Nova de São Pedro (Azambuja, Portugal) (Figura 1) implica obrigatoriamente referir um dos ícones desta colecção - as placas de tear. Estes artefactos foram identificados logo em 1937, sendo referidos ao longo das $31 \mathrm{cam}$ panhas de escavações realizadas por Afonso do Paço e Eugénio Jalhay (este último até 1950), bem como nas intervenções efectuadas no âmbito do projecto VNSP 3000 - Vila Nova de São Pedro, de novo, no $3^{\circ}$ milénio (Arnaud et al, 2017; Martins et al, 2019).

Este trabalho visa a apresentação de 11 placas, depositadas no Museu Arqueológico do Carmo (MAC), que apresentam em uma das suas superfícies representações iconográficas interpretadas como zoomórficas. No espólio existente no Museu Hipólito Cabaço (Alenquer), encontra-se outra com representação de cervídeo, placa esta publicada por A. Paço e E. Jalhay em 1939 e recolhida numa das duas primeiras campanhas (Paço e Jalhay, 1939: fig. $21-\mathrm{n}^{\circ}{ }^{\mathrm{O}}$ ). Até à data, não temos conhecimento de outras representações zoomórficas nos pequenos conjuntos de placas de VNSP que se encontram em outras instituições, podendo por isso este número ser aumentado em trabalhos futuros.

A sua singularidade levou a que, logo em 1940, estas fossem apresentadas por Afonso do Paço no Congresso do Mundo Português, realçando as suas particularidades face a outros exemplares da Península Ibérica (Paço, 1941). Nessa publicação, os desenhos esquemáticos de 58 placas encontram-se organizados por categorias iconográficas, apresentando paralelos com representações em outros artefactos (vasos cerâmicos ou pinturas rupestres), da Península Ibérica. Neste primeiro trabalho é também abordada a temática funcional, realçando que as perfurações não apresentam sinais de desgastes, levantando a hipótese de que Vila Nova de São Pedro fosse também um centro produtor destes objectos (Paço, 1941).

Ao longo das últimas décadas as placas de tear de VNSP foram sendo referidas em diversos trabalhos (e.g. Diniz, 1994), encontrando-se a sua sistematização tipológica, iconográfica e enquadramento crono-cultural num artigo de síntese (Arnaud, 2013), antecedendo o trabalho monográfico de inventariação e estudo que se encontra em preparação pelos signatários.

\section{O OBJECTO DE ESTUDO: AS PLACAS COM REPRESENTAÇÕES ZOOMÓRFICAS}

$\mathrm{Na}$ colecção de placas de tear do MAC estão identificadas 11 placas com 13 representações zoomórficas, sete destas de cervídeos (machos) e seis de quadrúpedes sem identificação da espécie.

\subsection{Técnica de execução e decoração}

No MAC encontram-se 515 placas de tear, todas elas de cerâmica, claramente padronizadas, de formato quadrangular ou rectangular, apresentando na grande maioria quatro perfurações. A técnica de execução da placa é manual, efectuando-se a perfuração com um objecto de perfil circular, procedendo-se ao alisamento das superfícies e arestas, bem como dos rebordos das perfurações. Foi possível observar em alguns destes objectos um pequeno rebordo exterior à perfuração, revelando-nos assim a direcção de perfuração e que, como esperado, esta foi feita previamente à cozedura.

Das 515 placas 246 não apresentam decoração, estando identificados 364 motivos iconográficos, existindo placas com apenas uma das superfícies e outras com as duas superfícies decoradas. No conjunto do MAC a maior percentagem de placas decoradas poderia ser entendida como resultante de uma opção de recolha, no campo porém, os trabalhos efectuados no âmbito do projeto VNSP3ooo, não levaram à identificação de placas lisas entre os vários "depósitos" de materiais ainda visíveis nas imediações do sítio arqueológico, como acontece com a cerâmica lisa ou com os restos de fauna (Martins et al, 2019; Francisco et al, 2020). Consideramos por isso que esta paridade, ou ligeira predominância, das placas decoradas face às lisas corresponde a uma opção técnica e ideo-tipológica nesta categoria artefactual. Os futuros trabalhos de inventariação de placas depositadas noutros museus poderão proporcionar novas leituras (Gráfico 1).

Relativamente à técnica de execução da decoração verifica-se que a grande maioria foi realizada através de incisão e apenas em 38 motivos foi usada a impressão. As incisões mostram as margens bem definidas, tendo perfil em $\mathrm{V}$ ou $\mathrm{U}$, podendo ser de reduzida espessura, correspondendo a uma incisão filiforme. Terão sido realizadas por elementos vegetais ou objectos metálicos num momento prévio à cozedura, sendo alisadas juntamente com a superfície da placa. 
Através do programa de arqueologia experimental realizado no âmbito do projecto $\mathrm{VNSP}_{3} \mathrm{Ooo}$ podemos afirmar que a decoração é realizada num momento posterior à execução da placa, numa fase adiantada da secagem, estando a argila já mais compactada e resistente. A incisão feita imediatamente depois da placa estar moldada apresenta as margens indefinidas e com rebordos exteriores, ficando o motivo iconográfico imperfeito e irregular.

Algumas placas mostram ainda o motivo seccionado pela perfuração, revelando-nos que a abertura do orifício foi realizada num momento posterior ao da execução da decoração.

Os motivos decorativos encontram-se, por agora, divididos em quatro tipologias iconográficas fundamentais: antropomórficos; zoomórficos; soliformes ou astrais e geométricos. A última categoria é a mais representada no conjunto.

Para efeitos descritivos foi designada como Superfície A aquela que tem o motivo zoomórfico e como Superfície B a oposta, podendo esta apresentar ou não gravações.

\subsection{Descrição iconográfica dos motivos zoomórficos}

VNSP3000/MAC/236 - Placa rectangular, com cantos arredondados, alisada e parcialmente fracturada. Apresenta marcas de acção de fogo e as superfícies estão muito erodidas. As perfurações não apresentam evidências de desgaste, nem o rebordo do processo de execução(Figura 2$)^{5}$.

Superficie A - Motivo interpretado como uma representação zoomórfica - um cervídeo, orientado para a esquerda. É formado por uma linha horizontal com $6,5 \mathrm{~cm}$, localizada no centro da placa, existindo na parte inferior desta linha dois conjuntos de traços verticais, paralelos entre si, com cerca de $1 \mathrm{~cm}$ de comprimento e $0,5 \mathrm{~cm}$ de distância entre cada conjunto de traços - as patas. O conjunto de traços mais à esquerda é oblíquo. Na parte superior da linha horizontal, na área à esquerda, surgem dois traços verticais, paralelos entre si, com cerca de $2,5 \mathrm{~cm}$ de comprimento e o, $5 \mathrm{~cm}$ de distância, dos quais parte um conjunto de pequenos traços oblíquos - as hastes. O primeiro tem 4 traços oblíquos e o segundo 6 traços. A técnica de execução utilizada foi a incisão,

5. Os desenhos das placas com representações zoomórficas foram realizados por César Neves. sendo as hastes e os membros inferiores filiformes. Estamos assim perante a representação de um cervídeo - macho/adulto, caracterizado pelas hastes ramificadas e membros inferiores dianteiros e traseiros. A disposição oblíqua dos membros inferiores dianteiros revela movimento, não sendo uma figura estática.

Superficie B - Não apresenta decoração. A superfície está bastante deteriorada não sendo possível afirmar se possuiu originalmente algum motivo iconográfico.

VNSP300o/MAC/269 - Placa rectangular, com cantos arredondados, alisada e parcialmente fracturada. Apresenta marcas de acção de fogo disseminadas e as superfícies erodidas. Apenas tem uma perfuração, de pequena dimensão, que não apresenta sinais de desgaste (Figura 3).

Superficie A - Motivo decorativo interpretado como uma representação zoomórfica - um cervídeo, orientado para a esquerda. É formado por duas linhas horizontais com cerca de 2,3 cm de comprimento, paralelas entre si que representam o dorso e ventre do animal. Na zona inferior surgem dois traços verticais de disposição oblíqua, paralelos entre si, com $0,5 \mathrm{~cm}$ de distância e 1, $8 \mathrm{~cm}$ de comprimento. Na parte superior surge representado o pescoço e com outros dois traços paralelos a cabeça com representação do olho e focinho. Sobre a extremidade da cabeça surgem onze traços verticais e oblíquos, com cerca de $1,5 \mathrm{~cm}$ de comprimento, que representam as hastes ramificadas. A técnica de execução utilizada foi a incisão.

Trata-se de uma representação de um cervídeo - macho/adulto, caracterizado pelas hastes ramificadas e membros inferiores dianteiros que estão dispostos obliquamente revelando movimento. A cabeça mostra pormenores anatómicos como o olho e focinho. Superficie B - Não apresenta decoração. A superfície está bastante deteriorada não sendo possível afirmar se possuiu originalmente algum motivo iconográfico.

VNSP3000/MAC/305 - Placa rectangular, com cantos angulosos, alisada e parcialmente fracturada. Apresenta marcas de fogo disseminadas e as superfícies erodidas. Possui duas perfurações, sem evidências de desgaste, mostrando uma delas ainda sedimento no seu interior (Figura 4).

Superficie A - Motivo interpretado como uma representação zoomórfica - um cervídeo, orientado para a direita. É formado por um conjunto de linhas horizontais com cerca de $4 \mathrm{~cm}$ de comprimento, 
paralelas entre si que representam o dorso e ventre do animal. Na zona inferior surgem dois traços verticais, paralelos entre si, com $0,5 \mathrm{~cm}$ de distância e $2 \mathrm{~cm}$ de comprimento, existindo outro traço vertical com a mesma dimensão na área mais à esquerda - as patas. Na parte superior surgem dois traços verticais, com cerca de 1,2 cm de comprimento, paralelos entre si, tendo o traço mais à esquerda 4 pequenos traços oblíquos e o traço mais à esquerda 3 traços oblíquos - as hastes. A técnica de execução utilizada foi a incisão, sendo as hastes filiformes.

Corresponderá a uma representação de um cervídeo - macho/adulto, caracterizado pelas hastes ramificadas, mostrando os membros inferiores rígidos correspondendo a uma figura estática.

Superfície $B$ - Superfície muito erodida, com gravação por incisão de um motivo considerado geométrico. É formado por dois traços horizontais paralelos entre si tendo na zona inferior dois pares de traços paralelos dispostos na vertical, estando a extremidade superior direita partida. Esta morfologia poderá ser caracterizada como zoomórfica, porém, não apresenta pormenores como as outras representações (cabeça ou hastes), por se encontrar fracturada no centro superior direito. Por questões estilísticas, optou-se, nesta fase, por incluir esta morfologia nos motivos geométricos estando, assim, fora desta análise.

VNSP300o/MAC/306 - Placa rectangular com cantos ângulosos e superfície alisada, estando fracturada no centro, mas permitindo a sua reconstituição integral. Mostra quatro perfurações que não apresentam evidências de desgaste, nem o rebordo da perfuração, indicando um alisamento pré-cozedura. Apresenta marcas de fogo pontuais e a decoração foi realizada por incisão (Figura 5 ).

Superficie A - Motivo interpretado como uma representação zoomórfica - um quadrúpede, orientado para a esquerda. É formado por uma linha horizontal com $6,5 \mathrm{~cm}$, que atravessa toda a superfície da placa. Na parte inferior desta linha surgem dois conjuntos de traços verticais, paralelos entre si, com cerca de $2 \mathrm{~cm}$ de comprimento e $0,5 \mathrm{~cm}$ de distância entre cada conjunto de traços. O último traço - mais à direita - poderá corresponder ao prolongamento do traço horizontal superior. Na parte superior da linha horizontal, na área mais à direita, surgem dois traços verticais, paralelos entre si, com cerca de 1,5 cm de comprimento e 0,5 cm de distância, dis- postos na oblíqua. É uma figura que ocupa todo o espaço operativo.

Confirma-se a representação de um quadrúpede, sendo impossível determinar a espécie. Tem membros inferiores dianteiros e posteriores, e os dois traços na área superior poderão representar orelhas ou chifres.

Superficie B - Morfologia enquadrável na categoria de motivos geométricos. Enquadrado nas linhas zig-zagueantes, com 7,2 cm de comprimento, composto por 9 segmentos curvos, tendo uma pequena bifurcação no topo. Este motivo poderia também ficar incluído nos motivos zoomórficos, correspondendo a um serpentiforme. No entanto, condicionantes estilísticas e interpretativas levam-nos a colocá-lo, por agora, nos motivos geométricos. Ocupa todo o espaço operativo estando ao centro da placa.

VNSP30oo/MAC/345 - Fragmento de placa com uma perfuração, com cantos angulosos e superfície polida. Mostra marcas de fogo em toda a superfície e a decoração foi realizada por incisão. A perfuração não apresenta sinais de desgaste (Figura 6).

Superficie A - Motivo interpretado como uma representação zoomórfica - parte das hastes de um cervídeo, orientado para a direita. Trata-se de uma peça muito fracturada, estando apenas conservada a porção superior direita de uma placa que deveria ter formato rectangular. A decoração é formada por um traço vertical, inclinado obliquamente e com cerca de $2 \mathrm{~cm}$ de comprimento, unindo uma série de 12 pequenos traços paralelos entre si, com cerca de $0,5 \mathrm{~cm}$, dispostos obliquamente. Corresponderá assim à representação parcial das hastes ramificadas de um cervídeo.

Superficie B - Não apresenta decoração. A superfície está bastante deteriorada não sendo possível afirmar se teve originalmente algum motivo iconográfico.

VNSP300o/MAC/403 - Placa rectangular, com cantos angulosos, alisada e parcialmente fracturada. Não tem marcas de fogo mas as superfícies encontram-se muito erodidas. Apresenta duas perfurações, com algum desgaste, mostrando rebordo resultante da perfuração pré-cozedura (Figura 7).

Superficie A - Motivo interpretado como uma representação zoomórfica - um cervídeo, orientado para a esquerda. É formado por duas linhas horizontais com cerca de $2 \mathrm{~cm}$ de comprimento, paralelas entre si que representam o dorso e ventre do ani- 
mal. Na zona inferior surgem dois traços verticais, de disposição oblíqua, paralelos entre si, com o, $5 \mathrm{~cm}$ de distância e $2 \mathrm{~cm}$ de comprimento - as patas. $\mathrm{Na}$ parte superior surge um traço vertical, com cerca de 1,5 cm de comprimento, tendo do lado direito quatro traços horizontais, paralelos entre si, e do lado esquerdo seis traços horizontais, paralelos entre si - as hastes. A técnica de execução utilizada foi a incisão, sendo as hastes filiformes.

Considera-se estar perante a representação de um cervídeo-macho/adulto, caracterizado pelas hastes ramificadas, mostrando os membros inferiores dianteiros numa posição oblíqua revelando movimento. Superficie B - Não apresenta decoração. A superfície está bastante deteriorada não sendo possível afirmar se teve originalmente algum motivo iconográfico.

VNSP300o/MAC/409 - Fragmento de placa com uma perfuração, com cantos arredondados e superfície erodida. Mostra marcas de fogo disseminadas e a decoração foi realizada por incisão. A perfuração não apresenta sinais de desgaste (Figura 8).

Superfície A - Motivo interpretado como uma representação zoomórfica - um quadrúpede, orientado para a direita. Localiza-se na parte direita da placa entre as duas perfurações. É formado por uma linha horizontal com $1,5 \mathrm{~cm}$, existindo na área inferior desta linha dois conjuntos de traços verticais, paralelos entre si, com cerca de $2 \mathrm{~cm}$ de comprimento e $0,2 \mathrm{~cm}$ de distância entre cada conjunto de traços. $\mathrm{Na}$ parte superior da linha horizontal, na área mais à esquerda, surgem dois traços verticais, paralelos entre si, com cerca de o, $8 \mathrm{~cm}$ de comprimento e o, $2 \mathrm{~cm}$ de distância. À direita desta figura surgem dois traços verticais que poderiam fazer parte de um outro motivo, impossibilitando a sua caracterização devido ao mau estado de conservação e fractura da placa.

Interpretado como uma representação de um quadrúpede, não sendo possível determinar a espécie. Possui membros inferiores dianteiros e posteriores, e os dois traços na área superior poderão representar orelhas ou cornos.

Superfície B - Não apresenta qualquer decoração.

VNSP300o/MAC/446 - Placa quadrangular, com cantos arredondados, alisada e parcialmente fracturada. Apresenta as quatro perfurações sem marcas de desgaste. As marcas de acção de fogo são cobridoras e a decoração foi feita por incisão (Figura 9). Superficie A - Motivo interpretado como uma re- presentação zoomórfica - um quadrúpede, orientado para a direita. É formado por duas linhas horizontais, com $5,5 \mathrm{~cm}$ de comprimento, paralelas entre si, existindo na área inferior desta linha dois conjuntos de traços verticais, paralelos entre si, com cerca de $3 \mathrm{~cm}$ de comprimento e $0,7 \mathrm{~cm}$ de distância entre cada conjunto de traços. Na parte superior da linha horizontal, na área mais à direita, surgem dois traços verticais, paralelos entre si, com cerca de 1,7 cm de comprimento e o, $4 \mathrm{~cm}$ de distância. Ocupa todo o espaço operativo da placa, estando enquadrada entre as 4 perfurações.

Estamos assim perante a representação de um quadrúpede, sendo impossível determinar a espécie. Tem membros inferiores dianteiros e posteriores, e os dois traços na área superior poderão representar orelhas ou cornos.

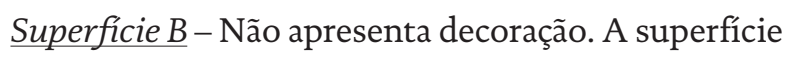
está bastante deteriorada, não sendo possível afirmar se teve originalmente algum motivo iconográfico.

Arestas - As quatro arestas estão também decoradas com traços incisos horizontais.

VNSP300o/MAC/475 - Placa quadrangular, com cantos angulosos, alisada e parcialmente fracturada. Apresenta marcas de acção de fogo pontuais e as três perfurações não mostram sinais de desgaste. A decoração foi realizada por incisão. Encontra-se em muito mau estado de conservação (Figura 10). Superficie A - Motivo zoomórfico interpretado como um cervídeo, orientado para a esquerda. É formado por duas linhas horizontais com cerca de $4 \mathrm{~cm}$ de comprimento, paralelas entre si que representam o dorso e ventre do animal. $\mathrm{Na}$ zona inferior surgem dois conjuntos de traços verticais de disposição oblíqua, paralelos entre si, com $0,2 \mathrm{~cm}$ de distância e 1,8 cm de comprimento - as patas. Na extremidade esquerda do traço superior inicia-se outro, de disposição vertical, ramificando-se na extremidade por 12 traços de disposição oblíqua, paralelos entre si e com cerca de 1,5 cm de comprimento - as hastes. Surgem ainda de ambos os lados dois pares de pequenos traços horizontais.

Representação de um cervídeo - macho/adulto, caracterizado pela haste ramificada e membros inferiores dianteiros que estão dispostos obliquamente, revelando movimento. $O$ conjunto de pequenos traços laterais poderão estar relacionados com a cabeça do animal.

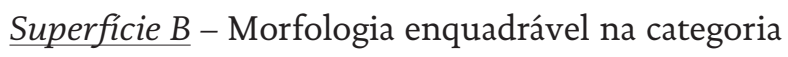


de motivos geométricos, formado por um conjunto de quatro linhas quebradas.

VNSP300o/MAC/490 - Placa rectangular, com cantos angulosos, alisada e parcialmente fracturada. Apresenta marcas de fogo pontuais e as quatro perfurações não mostram evidências de desgaste. A decoração foi realizada através de incisão (Figura 11). Superficie A - Motivo interpretado como uma representação zoomórfica - um quadrúpede, orientado para a direita. É formado por uma linha horizontal com $5,7 \mathrm{~cm}$, que atravessa toda a superfície da placa. Na parte inferior desta linha surgem dois conjuntos de traços verticais, paralelos entre si, com cerca de $2 \mathrm{~cm}$ de comprimento e $0,5 \mathrm{~cm}$ de distância entre cada conjunto de traços. Na parte superior da linha horizontal, na área mais à direita, surgem dois traços verticais, paralelos entre si, com cerca de $2 \mathrm{~cm}$ de comprimento e o, $5 \mathrm{~cm}$ de distância. Ocupa todo o espaço operativo da superfície da placa.

Representação de um quadrúpede, não sendo possível determinar a espécie. Apresenta membros inferiores dianteiros e posteriores, surgindo no membro direito um pequeno traço horizontal que poderá corresponder à representação de pata. Os dois traços na área superior representarão orelhas ou cornos.

Superfície $B$ - Morfologia enquadrável na categoria de motivos soliformes, formado por um conjunto de linhas radiais. Encontra-se muito fracturada.

VNSP3000/MAC/491 - Placa rectangular, com cantos angulosos, alisada e parcialmente fracturada. Apresenta marcas de fogo pontuais e três perfurações, sem evidência de desgaste. A decoração foi realizada através de incisão (Figura 12).

Superficie A - Apresenta três motivos zoomórficos. No topo da peça surge um motivo zoomórfico muito esquemático, orientado para a direita e formado por duas linhas horizontais, paralelas entre si, com cerca de $3 \mathrm{~cm}$ de comprimento, que se juntam à esquerda. Neste ponto iniciam-se duas linhas verticais, com $1 \mathrm{~cm}$ de comprimento. Trata-se assim de um quadrúpede muito esquemático, tendo representado corpo e extremidades na cabeça - cornos ou orelhas.

Ao centro da placa surge outro motivo zoomórfico, orientado para a direita, sendo observáveis dois traços, paralelos entre si e com $5 \mathrm{~cm}$ de comprimento, existindo na extremidade esquerda outros dois, com 1,5 cm de comprimento, de disposição vertical com inclinação oblíqua. Trata-se da representação de um quadrúpede muito esquemático, que mostra ventre e dorso e os membros inferiores traseiros.

Sob o zoomorfo anterior, na área central da placa, surge a terceira representação zoomórfica. Está orientada para a esquerda e é formada por um conjunto de traços horizontais, com cerca de $2 \mathrm{~cm}$ de comprimento, paralelos entre si, sendo que na área mais à esquerda surgem outros dois pequenos traços de disposição vertical com inclinação oblíqua. Na parte superior, dois traços verticais, paralelos entre si e com cerca de 1,3 cm de comprimento, formam o pescoço, surgindo da extremidade seis traços de reduzida dimensão e disposição circular. Estamos perante um quadrúpede, possivelmente um veado com início de hastes ou cornos, mostrando pormenores como a cabeça e focinho. Os membros inferiores dianteiros dispostos obliquamente revelam movimento.

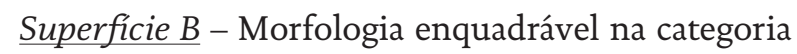
de motivos geométricos. Trata-se de um espinhado formado por um conjunto de seis linhas horizontais, paralelas entre si, cruzadas por uma série de traços oblíquos de diferentes orientações. Ocupa todo o espaço operativo da superfície da placa.

\section{PROVENIÊNCIA E CONTEXTO ARQUEOLÓGICO}

O povoado calcolítico de Vila Nova de São Pedro foi escavado de forma intensiva durante 31 anos, sendo que a metodologia utilizada não permite uma clara correlação estratigráfica entre materiais arqueológicos recolhidos e contextos de proveniência. Como referido anteriormente, desde a primeira publicação em 1939 que as placas de tear são descritas e representadas quer por desenho esquemático, quer em fotografia (Paço e Jalhay, 1939; 1942; 1943; Jalhay e Paço, 1945; Paço, 1941, Paço e Costa Arthur, 1952), não sendo, no entanto, referida a origem, no campo, destes materiais.

Através da análise dos dados publicados sabemos que as placas foram recolhidas na zona entre o reduto central - "1aㅗ linha de muralha" - e " $2^{\underline{2}}$ linha de muralha", espaço onde foram identificadas diversas áreas habitacionais com fundos de cabana e outras estruturas pétreas mas, também, no centro do povoado, no interior do reduto central, surgindo dispersas por toda a área escavada. Não foi referida nenhuma concentração de placas que poderia indicar áreas funcionais de execução, armazenamento ou produção têxtil. 
Na descrição estratigráfica do corte efectuado por H. Savory é referida a presença de placas perfuradas nos três estratos identificados (Savory, 1970), revelando assim que esta categoria artefactual encontrava-se presente desde a fundação do povoado até ao seu abandono, enquadrando-se cronologicamente ao $3^{\circ}$ milénio A.C.. Outras correlações possíveis entre placas decoradas e placas lisas ou entre motivos iconográficos não são referidas nos registos disponíveis.

Nas sondagens realizadas no âmbito do projecto VNSP 3000 , foram recolhidos alguns destes elementos artefactuais, a maioria fragmentados. Num contexto datado de meados do $3^{\circ}$ milénio cal BC foi recolhida uma placa inteira quadrangular com apenas duas perfurações - em ângulos opostos da mesma extremidade - e um fragmento com decoração geométrica (Martins et al, 2019).

Das 11 placas aqui apresentadas quatro encontravam-se inéditas (placas 236, 305, 403 e 409), sendo que a placa 269 poderá corresponder à peça publicada em 1940 e 1945, surgindo incompleta sem a representação da cabeça e hastes do cervídeo (Paço, 1941: 48 - fig. 1 nº 7; Jalhay e Paço, 1945: 66 - fig. 8 $\mathrm{n}^{\circ} 7$ ). As placas 446, 475 e 490 foram também dadas à estampa mais recentemente (Arnaud, 2013: 453) (Figura 13).

Em suma, as placas de tear, constituem em VNSP um artefacto de ampla dispersão cronológica e espacial no entanto, o papel dos factores pós-deposicionais na dispersão destes materiais não é fácil de avaliar.

\section{REPRESENTAÇÕES ZOOMÓRFICAS DAS SOCIEDADES CAMPONESAS: ARTEFACTOS MÓVEIS E IMÓVEIS,} ANIMAIS MITIFICADOS E ANIMAIS REAIS

Estudar as sociedades agro-pastoris implica necessariamente uma abordagem de conjunto, onde o debate sobre os elementos da cultura material se relaciona com os dados sobre restos faunísticos e com as manifestações rupestres, móveis ou imóveis. Os motivos representados em diferentes suportes tais como recipientes domésticos, objectos ideotécnicos ou grafismos rupestres esquemáticos farão parte do mesmo universo conceptual e simbólico destas comunidades, levando-nos a aceitar que poderão ter significados e papéis similares.

O esquematismo inerente a estas representações im- pede-nos de, em algumas destas placas, identificar categoricamente a espécie representada, e por isso o motivo é classificado apenas como figura quadrúpede. Nestes casos, a ausência de pormenores anatómicos foi uma opção prévia à execução do motivo, e fez parte de um discurso gráfico reconhecido pela comunidade onde a determinação da espécie não parece ser valorizada.

A identificação do quadrúpede é-nos permitida pela presença de membros posteriores ou anteriores, corpos geralmente alongados e de formato sub-rectangular, sendo que outros pormenores anatómicos como hastes, cornos, focinho, cauda, pelagem, patas e cascos poderão permitir a identificação da espécie. A representação de pormenores anatómicos como as hastes, o falo ou morfologia do ventre permitirá uma atribuição sexual, sendo que a associação entre animais semelhantes de diferentes tamanhos poderá representar machos e fêmeas ou adultos e juvenis. Para além destes pormenores anatómicos, em diferentes suportes, encontram-se também relacionados quer com o meio natural envolvente (coberto vegetal e estações do ano), quer com cenas de cópula ou fases do ciclo reprodutivo dos animais, demonstrando o cruzamento sistemático entre as actividades económico-sociais e simbólicas destas comunidades.

Entre os motivos zoomórficos, os quadrúpedes surgem frequentemente na arte esquemática, da Península Ibérica, em pintura e em gravura, surgindo nos mais variados suportes (abrigos, rochas ao ar livre) e com algumas variantes estilísticas como os motivos pectiniformes (Sanchidrián, 2001: 447) ou, classificados como não quadrúpedes, nos quais se incluem aves, anfíbios, peixes e colubrídeos. Encontramos paralelos estilísticos com as representações de Vila Nova de São Pedro, sugerindo uma efectiva uniformidade simbólica e conceptual das comunidades agro-pastoris (Martins, 2016).

No território actualmente português destaca-se o ciclo artístico de gravuras esquemáticas do Vale do Tejo pela diversidade e quantidade de representações zoomórficas cujas características estilísticas possibilitaram a definição de numerosas espécies, selvagens e domésticas (Gomes, 2010), onde os quadrúpedes são dominantes. De Norte a Sul do país encontram-se diversos abrigos com algumas representações zoomórficas pintadas - Forno da Velha, Fonte Santa, Fraga do Gato, Fraga d'Aia, Faia 1, Ribeiro das Casas, Lapa dos Gaivões, Abrigo Pinho Monteiro (Martins, 2013), e entre uma maioria de quadrúpedes indeter- 
minados, destacam-se os cervídeos como a espécie mais identificável.

A semelhança iconográfica entre motivos presentes em suportes rupestres e em artefactos móveis tem sido abordada por diversos investigadores peninsulares, sendo de referir os trabalhos desenvolvidos nas áreas de Valência e Alicante com a definição de horizontes artísticos relacionando cerâmicas cardiais com motivos macro-esquemáticos (Martí Oliver e Hernández Pérez, 1988; Martí Oliver, 2006; Hernández Pérez e Segura Martí, 2002). A utilização de representações gráficas em artefactos provenientes de contextos estratigráficos seguros permite uma atribuição cronológica relativa a motivos idênticos existentes em suportes rupestres e, para os quais, não é possível efectuar uma datação directa. Diversos estudos têm permitido a definição de sequências crono-estilísticas para alguns motivos esquemáticos, tendo em conta artefactos, contextos, tipologias e semelhanças formais, levando a uma aproximação dos conteúdos simbólicos destas comunidades agro-pastoris (Carrasco Rus et al, 2006; Martins, 2016).

A nível estilístico encontram-se diferenças entre representações em artefactos móveis e em suportes rupestres. Se em artefactos, como as placas de tear ou recipientes cerâmicos, os motivos são maioritariamente lineares, sem profundidade ou espessura, nas gravuras e pinturas surgem com contornos e preenchimento interior, correspondendo a figuras com volume, formas anatómicas e uma maior impressão de movimento. No caso dos quadrúpedes indiferenciados torna-se ainda mais difícil efectuar paralelismos entre figuras, pois a ambiguidade destas representações não permite considerações objectivas.

\subsection{Quadrúpedes indeterminados}

No conjunto analisado foram definidas quatro representações de zoomorfos cujas características tipológicas não permitem a atribuição de espécie, ficando assim classificados como quadrúpedes indeterminados. Nenhum deles apresenta pormenores anatómicos claramente identificáveis, podendo as extremidades existentes nas cabeças dos motivos 306, 409, 446 e 490 ser consideradas como cornos ou chifres, estando assim perante a representação de um bovídeo ou de uma cabra/bode (Figuras 5, 8, 9 e 11). Esta última hipótese é particularmente proposta no quadrúpede da placa 306 cujos traços oblíquos (cornos) têm paralelo estilístico com as representa- ções de cabras do Vale do Tejo (Gomes, 2010: 273). Os motivos existentes nas placas 306 e 490 mostram grande semelhança formal, tendo ambos o prolongamento do traço central até à extremidade do membro inferior posterior, podendo assim ter sido executados pelo mesmo indivíduo (Figuras 5 e 11).

Na placa 409 observa-se uma cena em que participam, possivelmente, dois motivos zoomorfos, um completo e de pequena dimensão, enquanto do outro apenas temos a representação de dois traços (Figura 8). Esta cena tem paralelo com a existente na placa 491 (Figura 12), bem como em diversos painéis com figurações rupestres onde está presente a associação de zoomorfos, possivelmente relacionados entre si por laços familiares - fêmea e cria.

Exceptuando o motivo existente na placa 409, todos os zoomorfos indeterminados ocupam o espaço operativo da superfície da placa, enquadrando-se entre as quatro perfurações, sendo figuras equilibradas e facilmente reconhecíveis.

\subsection{Cervídeos}

Os cervídeos (veados, gamos e/ou corços), são a família animal, identificável, mais representada na iconografia das comunidades neolíticas e calcolíticas, apresentando caracteres anatómicos que permitem esta fácil identificação. A representação das hastes ramificadas, típicas dos machos adultos, que atingem o auge no Verão e caem no Inverno, reportam-nos imediatamente para o veado (Cervus elaphus) macho, sendo mais difícil de definir as fêmeas, os juvenis ou mesmo os machos adultos após acasalamento e perda de hastes. O dimorfismo sexual acentuado nos veados permite uma maior diferenciação sexual, factor menos presente no que diz respeito aos corços (C. capreolos). Durante a maior parte do ano, os veados reúnem-se em manadas, de machos, fêmeas e crias, existindo, porém, alguns machos solitários, que apenas se reúnem em período de acasalamento que ocorre no Outono.

Do ponto de vista simbólico seria certamente um animal muito especial, selvagem, forte e que todos os anos se regenera, mudando as grandes hastes e recomeçando um novo ciclo. Seria uma importante fonte de proteína mas também objecto de aproveitamento de recursos secundários como as hastes, matéria-prima base de utensilagem diversificada e mesmo em possíveis cerimónias ou rituais com manipulação de partes do esqueleto como o crânio e respectivas hastes. 
O peso destes animais no universo simbólico encontra-se plasmado nas inúmeras representações existentes em todo o tipo de suportes: rupestres (pintura e gravura), cerâmicas domésticas, indústria óssea e artefactos ideotécnicos, mas é na denominada cerâmica simbólica campaniforme que encontramos diversas representações de cervídeos, geralmente associados a motivos oculados ou soliformes, bem como a composições geométricas mais ou menos elaboradas, gravadas por incisão nas áreas mais visíveis e destacadas das taças ou vasos. Tradicionalmente associada a contextos funerários, esta cerâmica surge igualmente em níveis de habitat, sendo os cenários da sua utilização e os possíveis conteúdos muito discutidos (Bueno Ramírez et al, 2017; Garrido Pena e López-Astilleros, 200o).

$\mathrm{Na}$ Estremadura portuguesa encontramos representações de cervídeos em recipientes cerâmicos com decoração simbólica campaniforme em contextos funerários, como as taças provenientes do Casal do Pardo - Palmela, sendo numa delas observáveis dois cervídeos, um claramente macho e outro fêmea ou juvenil (Horta e Bubner, 1974: 123) e ainda no Tholos da Tituaria (Cardoso et al., 1996: fig. 58) com a representação de um veado macho com hastes ramificadas. Este tipo de cerâmica simbólica surge também em contextos domésticos, como no Castro da Portucheira (Harrison, 1977), ou na ocupação calcolítica de Freiria (Cardoso et al., 2013: 532).

No Sul do território português, no sítio de planície da Quinta do Estácio 14 (Beja), fazendo parte num conjunto de recipientes de estilo Ciempozuelos, foi identificado um fragmento de cerâmica simbólica com a representação de dois veados machos caracterizados pelas hastes ramificadas de cariz esquemático (Soares, 2017: 52).

Nos Perdigões foi também identificado, na fossa 7 , um fragmento de cerâmica com representação de diversas hastes de cervídeos (Valera, 2015: 17), e num contexto funerário - Tholos 2 - datado entre 2575-220o BC, uma admirável estatueta de marfim representando um cervídeo (Valera et al, 2014: 25). No numeroso conjunto de artefactos ideotécnicos recolhidos em contextos funerários deste complexo sítio, surgem diversas falanges de cervídeos afeiçoadas e/ou decoradas com linhas zigzagueantes, idênticas às existentes em ídolos cilíndricos com tatuagens faciais (Valera, 2015: 10).

Permanece como um dos exemplares mais icónicos a taça do Tholos 15 de Los Millares que, além da re- presentação dos olhos oculados/solares, apresenta três veados, sendo um claramente macho e os restantes, provavelmente, fêmeas (Leisner e Leisner, 1943, est.20). Esta mesma composição surge noutra taça do Tholos 7 de Los Millares onde um veado macho com hastes ramificadas encontra-se rodeado por outros cinco cervídeos, possivelmente fêmeas, apresentando também possíveis representações soliformes ou oculados (Leisner e Leisner, 1943, est. 12). Nestas peças, temos uma composição que engloba os dois motivos mais representados na decoração da cerâmica simbólica calcolítica - cervídeos e motivos solares -, mostrando a importância desta associação, tal como se verifica na placa 409. Um pormenor destas duas composições é que em ambas alguns dos cervídeos encontram-se com a cabeça virada para trás, olhando directamente para o grande macho, podendo corresponder a algum tipo de diferenciação sexual ou etária.

Outra peça icónica é a taça campaniforme com decoração simbólica do povoado de Las Carolinas (Madrid), onde surgem diversos cervídeos, alinhados e ao redor de toda a taça, acompanhados por motivos soliformes (Leisner, 1961). As representações de cervídeos mostram na extremidade superior as ramificações das hastes, sendo que os membros inferiores surgem em número de seis, podendo representar movimento. Estaremos assim perante uma parada ou desfile de cervídeos relacionados directamente com o astro solar, observáveis de todos os lados da taça. Um dos motivos soliformes encontra-se exactamente no meio das hastes de um cervídeo, lembrando a adição e transmutação verificada na rocha 158 do núcleo de São Simão do Vale do Tejo (Gomes, 2010: 266).

A temática de alinhamento de cervídeos está presente em outros exemplares campaniformes, como na taça de Brenes (Carmona) (Harrison et al, 1976), ou, com apenas uma representação de cervídeo, como em El Ventorro (Madrid) (Priego e Quero, 1992: 232) ou em La Escarapela (Toledo) (Munoz, 1998). No Tholos de San Blas (Cheles, Badajoz) foi identificado um vaso globular com decoração impressa representando um alinhamento de zoomorfos esquemáticos interpretados como cervídeos ou cabras (Hurtado, 2004: 107).

As representações de cervídeos presentes nas placas de tear de Vila Nova de São Pedro apresentam igualmente paralelos estilísticos com as numerosas representações existentes em sítios com arte rupestre 
em toda a Península Ibérica, quer em gravuras quer em pinturas (Figura 14). Desde os grandes penedos e blocos horizontais com arte Atlântica aos abrigos inacessíveis com pinturas esquemáticas as representações de cervídeos surgem como elemento estruturante de diversas cenas e mitografias.

Destacando o já referido núcleo de gravuras do Vale do Tejo, axis mundi de um santuário rupestre, onde as representações de cervídeos têm um papel estruturante na organização crono-cultural e simbólica, surgem representações de grandes veados desde o Epipaleolítco até ao Neolítico final, fazendo parte de cenas e de transmutações simbólicas (Gomes, 2010: 263). As características ecológicas desta espécie são referenciadas, surgindo animais adultos com as hastes no auge do seu desenvolvimento, animais juvenis, fêmeas que poderão estar grávidas e crias. Os paralelos estilísticos com as representações de Vila Nova de São Pedro são abundantes, destacando-se a armação rígida do cervídeo da rocha 56.4 do Cachão do Algarve com a existente na placa 305 (Figura 4), ou as exuberantes hastes de vários veados da rocha 49 do Fratel (Gomes, 2010: 265), com as representações das placas 269, 345 e 475 (Figuras 3, 6 e 10). Nos abrigos com arte esquemática pintada surgem igualmente diversas cenas onde o cervídeo - o grande veado - é o protagonista, quer numa cena explícita de caça, como na Fraga d'Aia (Jorge et al, 1988), ou numa cena de caracter ritual ou simbólico, como na Lapa dos Gaivões (Martins, 2016). Neste grande abrigo, do maciço quartzítico da Serra de São Mamede (Arronches), temos uma cena onde uma figura antropomórfica, munida de uma corda ou laço, encontra-se rodeada por quatro cervídeos - dois veados machos e outros dois prováveis, fêmeas ou juvenis (Idem, 2016). O antropomorfo lança a corda sobre um dos veados, sendo esta acção possivelmente ritual ou mitográfica, visto dificilmente ser possível este tipo de caçada, revelando assim a importância desta espécie no universo simbólico destas comunidades.

A caça ao veado surge também representada no interior de monumentos megalíticos, como observamos na extraordinária cena existente num dos esteios da Orca dos Juncais, onde um conjunto de antropomorfos, munidos de arco e acompanhados por canídeos, confrontam diversos zoomorfos definidos como veados (Cruz, 200o).

\section{OS ZOOMORFOS DAS PLACAS DE VILA NOVA DE SÃO PEDRO E A TECELAGEM}

As representações zoomórficas existentes nas placas de tear de Vila Nova de São Pedro integram-se assim no vasto universo da simbólica das comunidades do $3^{\circ}$ milénio A.C., sendo que até ao momento, no povoado, não foram registadas semelhantes representações zoomórficas em outros artefactos, podendo, porém, alguns objectos ser interpretados como representações de animais (Arnaud e Fernandes, 2005: 213). Destaca-se ainda a estatueta de osso classificada como antropo-zoomórfica, que representará uma hibridação entre mulher/homem e felino, evidenciada pelo prognatismo da face, com nariz largo e longo e orelhas muito pequenas (Gomes, 2005: 168). Estes objectos móveis que representam figuras mistas poderão estar relacionados com prácticas rituais e simbólicas, de influências muito diversificadas, mas também com acções quotidianas do grupo.

Outra questão que se levanta relativamente a VNSP é que apesar da abundância de cerâmica campaniforme, dominando o estilo internacional ou marítimo, não estão registados motivos zoomórficos nos fragmentos recuperados. Esta ausência pode traduzir uma questão cronológica - em que os cervídeos são representações próprias da cerâmica campaniforme tardia? ou a representação destes animais é, sobre vasos campaniformes, que para além de tardios, são próprios de espaços de necrópole?

O papel que os animais possuem na construção dos sistemas simbólicos pré-históricos e, a mais ou menos, equívoca relação estabelecida com o seu significado económico continua em discussão. Os cervídeos fazem parte da abundante fauna de VNSP (Detry et al, 2020; Francisco et al, 2020) resultante da sua utilização quer como fonte primária de alimentação, quer como de aproveitamento de recursos secundários.

$\mathrm{Na}$ abundante indústria óssea (furadores, agulhas, cabos) de VNSP, são numerosos os artefactos executados sobre hastes de veados que podem ter sido recolhidas no período pós-acasalamento, quando estas caem naturalmente.

A presença de representações de cervídeos nas placas de tear insere-se num complexo universo gráfico onde diversas tipologias de símbolos (geométricos, antropomórficos, estiliformes), foram escolhidas para ficarem gravadas na argila. Esta escolha, sem- 
pre intencional, corresponderá a programas compositivos que poderão ou não ser predefinidos antes da execução, podendo também existir uma especialização técnica.

O desconhecimento dos sistemas de produção locais, bem como da organização social da comunidade impedem-nos, por agora, de tecer mais considerações sobre a produção das placas de tear e iconografia associada. Admite-se, no entanto, que a face gravada pudesse ser vista por quem tece, sugerindo assim uma posição particular para estes objectos, num tear horizontal ou vertical. Ao mesmo tempo, certos motivos podem representar um determinado movimento na acção de tecer, que poderá originar padrões distintos, funcionando como uma mnemónica visual. Noutra hipótese, os próprios motivos geométricos gravados nas placas corresponderão ao padrão produzido por determinada organização e disposição das mesmas no tear horizontal ou vertical. A relação símbolo-artefacto-acção poderá ser efectiva e esperamos levantar hipóteses através do programa de arqueologia experimental que temos vindo a desenvolver.

A escassez de representações explícitas da natureza (elementos vegetais, nuvens, água, solo, entre outros) nos programas iconográficos das sociedades pré-históricas é colmatada com a representação de animais que fazem parte das paisagens quotidianas e simbólicas destas comunidades.

Os zoomorfos, reais ou mitificados, eram representados em distintos suportes, fazendo parte do quotidiano, quer pela presença efectiva, quer em relatos transmitidos oralmente, materializados em gravações ou pinturas. Mais do que uma possível atribuição cronológica, os paralelos iconográficos permitem confirmar uma uniformidade cultural, em que o universo conceptual e simbólico é idêntico, conduzindo à execução de motivos análogos em comunidades distintas e espacialmente distantes.

As placas de tear de Vila Nova de São Pedro permitem uma abordagem transdisciplinar, desde a cadeia operatória da sua produção, execução iconográfica, funcionalidade e método de utilização, levando a que aspectos como organização social, económica e simbólica sejam alcançados com o estudo desta categoria artefactual.

Os cervídeos como elemento gráfico circulam entre diferentes ambientes, presentes em habitats, necrópoles e santuários rupestres. A sua funcionalidade simbólica concretiza-se em ambientes formalmente metafisicos como os esteios de uma anta ou um painel rochoso, mas também em objectos de eminente natureza doméstica, como esses meios de produção que são as placas de tear, numa demonstração óbvia da rede complexa de significados e usos que marca as sociedades humanas.

\section{BIBLIOGRAFIA}

ARNAUD, José M.; FERNANDES, Carla V., eds. (2005) Construindo a Memoria - As Colecções do Museu Arqueológico do Carmo. Lisboa. Associação dos Arqueólogos Portugueses.

ARNAUD, José M. (2013) - "Reflexões em torno das placas de cerâmica com gravuras de Vila Nova de S. Pedro (Azambuja)". ARNAUD, MARTINS e NEVES (coords.) Arqueologia em Portugal - 150 Anos. Associação dos Arqueólogos Portugueses, Lisboa, pp. 447-455.

ARNAUD, José M.; DINIZ, Mariana; NEVES, César; MARTINS, Andrea (2017) - Vila Nova de São Pedro - de novo, no 3. milénio. Um projecto para o futuro. Arqueologia e História, 66-67, Associação dos Arqueólogos Portugueses, Lisboa, pp. 7-17.

BUENO RAMÍREZ, Primitiva; BARROSO BERMEJO, Rosa; BALBÍN-BEHRMANN, Rodrigo (2017) - Redefining Ciempozuelos. Bell-Beaker culture in Toledo? Sinos e Taças - Junto ao oceano e mais longe. Aspectos da presença campaniforme na Península Ibérica, Estudos e Memórias, 10, Uniarq, pp. 324-341.

CARDOSO, João Luís; LEITÃO, Manuel, FERREIRA, Octávio da Veiga; NORTH, Christopher Thomas, MEDEIROS, J. P. e SOUSA, Fialho de (1996) - O monumento préhistórico de Tituaria, Moinhos da Casela (Mafra), Estudos Arqueológicos de Oeiras, 6, Oeiras. pp. 135-193.

CARDOSO, João Luís; CARDOSO, Guilherme; ENCARNAÇÃO, José (2013) - O Campaniforme de Freiria (Cascais). Estudos Arqueológicos de Oeiras, 20, Oeiras, Câmara Municipal, pp. 525-588.

CARRASCO RUS, Javier; NAVARRETE ENCISO, María; PACHÓN ROMERO, Juan (2006) - Las manifestaciones rupestres esquemáticas y los suportes muebles en Andalucía. Martínez García, J. e Hernández Pérez, M. (eds) - Arte Rupestre Esquemático en la Península Ibérica - Congreso, Comarca de Los Vélez, pp. 85-118.

CRUZ, Domingos (200o) - Roteiro Arqueológico de Vila Nova de Paiva, Vila Nova de Paiva: Câmara Municipal de Vila Nova de Paiva, 46 p.

DETRY, Cleia; FRANCISCO, Ana Catarina; DINIZ, Mariana; MARTINS, Andrea; NEVES, César; ARNAUD, José M. (2O2O) - Estudo zooarqueológico das faunas do Calcolítico final de Vila Nova de São Pedro (Azambuja, Portugal): Campanhas de 2017 e 2018. ARNAUD, J. M., NEVES, C. e MARTINS, A. (coords.) - Arqueologia em Portugal - 2020 - Estado da Questão. 
DINIZ, Mariana (1994) - Pesos de tear e tecelagem no calcolitico em Portugal. Trabalhos de Antropologia e Etnologia. Porto. Actas do Primeiro Congresso de Arqueologia Peninsular, 34: 3-4, pp. 133-149.

FRANCISCO, Ana Catarina; DETRY, Cleia; NEVES, César; MARTINS, Andrea; DINIZ, Mariana; ARNAUD, José M. (2020) - As faunas depositadas no Museu Arqueológico do Carmo provenientes de Vila Nova de São Pedro (Azambuja): as campanhas de 1937 a 1967, ARNAUD, J. M., NEVES, C. e MARTINS, A. (coords.) - Arqueologia em Portugal 2020 - Estado da Questão.

GARRIDO PENA, Rafael; LÓPEZ-ASTILLEROS, Kenia (200o) - Visiones sagradas para los líderes. Cerâmicas campaniformes com decoración simbólica en la Península Ibérica, Complutum, 11, pp. 285-300.

GOMES, Mário Varela (2005) - O sagrado em Vila Nova de São Pedro. Antigas e novas perspectivas. In: Arnaud, J. M. e Fernandes, C. V., eds. Construindo a Memoria - As Colecções do Museu Arqueológico do Carmo. Lisboa. Associação dos Arqueólogos Portugueses, pp. 165-178.

GOMES, Mário Varela (2010) - Arte Rupestre do Vale do Tejo - Um Ciclo Artístico-Cultural Pré e Proto-Histórico, Faculdade de Ciências Sociais e Humanas, Universidade Nova de Lisboa, 3 vols, (Dissertação de Doutoramento, texto policopiado).

HARRISON, Richard J. (1977) - The Bell Beaker Cultures of Spain and Portugal. American School of Prehistoric Research Bulletin, 35. American School of Prehistoric Research, Cambridge-Massachussets.

HARRISON, Richard J.; BUBNER, Thomas; HIBBS, V. A. (1976) - The beaker pottery from El Acebuchal, Carmona (Prov. Sevilla). Madrider Mitteilungen, XVII, pp. 79-141.

HERNÁNDEZ PÉREZ, Mauro; SEGURA MARTÍ, Josep, coord. (2002) - La Sarga. Arte rupestre y território, Ediciones del Museu de Alcoi, Caja de Ahorros del Mediterráneo, Alcoy, $213 \mathrm{p}$.

HORTA, Maria Amélia; BUBNER, Thomas (1974-1977) Novos materiais de Palmela, O Arqueólogo Português, Serie III, VII-IX, Lisboa, pp. 113-124.

HURTADO, Víctor Hurtado (2004) - San Blas, the discovery of a large chalcolithic settlement by the Guadiana river, Journal of Iberian Archaeology, Vol. 6, Porto: ADECAP, pp. 93-116.

JALHAY, Eugénio; PAÇO, Afonso (1945) - El castro de Vilanova de San Pedro. Actas y memorias de la Sociedad Espanola de Antropologia: Etnografia y Prehistoria. Madrid, 20, pp. 5-93.

JORGE, Vítor Oliveira; BAPTISTA, António Martinho; JORGE, Susana Oliveira; SANCHES, Maria de Jesus; SILVA, Eduardo; SILVA, Margarida; CUNHA, Ana Leite da (1988) O abrigo com pinturas rupestres da Fraga d'Aia (Paredes da Beira - São João da Pesqueira) - Notícia preliminar, Arqueologia, nํ18, Dezembro de 1988, Porto, pp. 109-130.
LEISNER, Georg; LEISNER, Vera (1943) - Die Megalithgräber der Iberischen Halbinsel.I. Der Süden. Romisch-Germanische Komission, 17. Berlín.

LEISNER, Vera (1961) - Innenverzierte Schalen der Kupferzeit auf der Iberischen Halbinsel. Madrider Mitteilungen, 2: 11-33.

MARTÍ OLIVER, Bernat; HERNÁNDEZ PÉREZ, Mauro (1988) - El Neolític Valencià - Art rupestre i cultura material, Servei d'Investigació Prehistòrica, Diputació de València, $114 \mathrm{p}$.

MARTÍ OLIVER, Bernat (2006) - Cultura material y arte rupestre esquemático en el País Valenciano, Aragón y Cataluña, In MARTÍNEZ GARCÍA, Julian; HERNÁNDEZ PÉREZ, Mauro, eds., Arte Rupestre Esquemático en la Península Ibérica - Congreso, Comarca de Los Vélez, pp. 119-147.

MARTINS, Andrea (2013) - A Pintura Rupestre Esquemática em Portugal: muitos sítios, mesmas pessoas?, in Arnaud, José; Martins, Andrea e Neves, César (Coord.) Arqueologia em Portugal - 150 anos, Associação dos Arqueólogos Portugueses, pp. 495-505.

MARTINS, Andrea (2016) - Abrigos de Arte Esquemática Pintada do Centro de Portugal: mundo simbólico e antropização da paisagem. Lisboa: Associação dos Arqueológos Portugueses (Monografias AAP, 3 ).

MARTINS, Andrea; NEVES, César; DINIZ, Mariana; ARNAUD, José (2019) - O povoado calcolítico de Vila Nova de São Pedro (Azambuja). Notas sobre as campanhas de escavação de 2017 e 2018. Arqueologia e História, $\mathrm{n} \times$ 69, Associação dos Arqueólogos Portugueses, pp. 133-167.

MUÑOZ, Isabel Kenia (1998) - El poblamiento desde el Neolítico Final a la Primera Edad del Hierro en la cuenca media del río Tajo. Universidad Complutense, Madrid (Tesis Doctoral inédita).

PAÇO, Afonso; JALHAY, Eugénio (1939) - A póvoa eneolítica de Vila Nova de S. Pedro: Notas sobre a $1^{\underline{a}}$ e $2^{\underline{a}}$ campanha - 1937 e 1938. Brotéria. Separata Lisboa. Vol. XXVIII: 6, pp. $2-46$.

PAÇO, Afonso (1941) - Placas de Barro de Vila Nova de S. Pedro. Congresso do Mundo Português, Porto. 1, pp. 233-251.

PAÇO, Afonso; JALHAY, Eugénio (1942) - A póvoa eneolítica de Vila Nova de S. Pedro. Notas sobre a $3^{\underline{a}}, 4^{\underline{a}}$ e $5^{\underline{a}}$ campanhas - 1939, 1940 e 1941. Brotéria, Separata, Lisboa, Vol. XXXIV: 6, pp. 2-31.

PAÇO, Afonso; JALHAY, E. (1943) - A póvoa eneolítica de Vila Nova de S. Pedro: Notas sobre a 6 ( $^{\mathrm{a}}$ campanha - 1942. Brotéria. Separata Lisboa. Vol. XXXVII: 1, pp. 4-27.

PAÇO, Afonso; COSTA ARTHUR, Maria Lourdes (1952) Castro de Vila Nova de São Pedro. I-1 $5^{\underline{a}}$ campanha de escavações (1951), Brotéria, Vol. LIV, Fasc. 3, Março 1952, pp. 6-25.

PRIEGO, Carmen; QUERO CASTRO, Salvador (1992) - El Ventorro, un poblado prehistórico de los albores de la metalurgia. Estudios de Prehistoria y Arqueologia Madrilenas, 8. 
SANCHIDRIÁN TORTI, José (2001) - Manual de arte prehistórico, Barcelona: Ariel Prehistoria, 549 p.

SAVORY, H. N. (1970) - A section through the innermost rampart of the chalcolithic castro of Vila Nova de S. Pedro, Santarem (1959). Actas das I Jornadas Arqueológicas. 1. Lisboa, Associação dos Arqueólogos Portugueses, pp. 133-148.

SOARES, Joaquina (2017) - Para uma leitura sociopolítica do campaniforme do Guadiana. Longas viagens com curta estada no Porto das Carretas. Sinos e Taças-Junto ao oceano e mais longe. Aspectos da presença campaniforme na Península Ibérica, Estudos e Memórias, 10, Uniarq, pp. 38-57.

VALERA, António Carlos; EVANGELISTA, Lucy Shaw; CASTANHEIRA, Patrícia (2014) - Zoomorphic figurines and the problem of Human Animal relationship in the neolithic and chalcolithic Southwest Iberia. MENGA - Revista de Prehistoria de Andalucía, noㅇ, pp. 15-41.

VALERA, António Carlos (2015) - "Ídolos falange”, Cervídeos e Equídeos. Dados e problemas a partir dos Perdigões. Apontamentos de Arqueologia e Património, 10, pp.7-20.
Placas de Tear - VNSP / MAC

Decoração

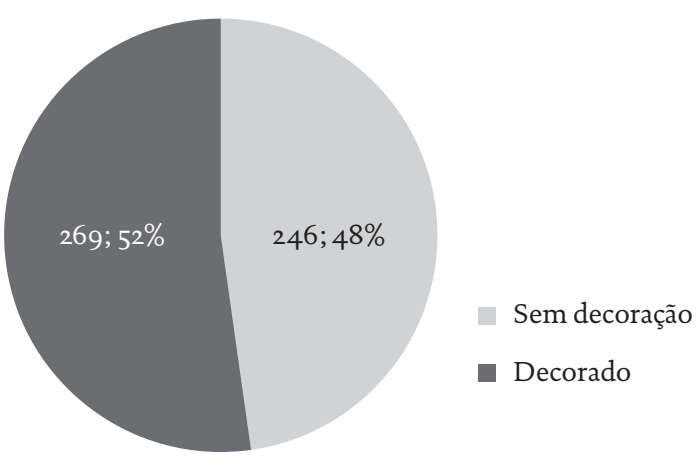

Gráfico 1 - Quantificação das placas de tear face à decoração.

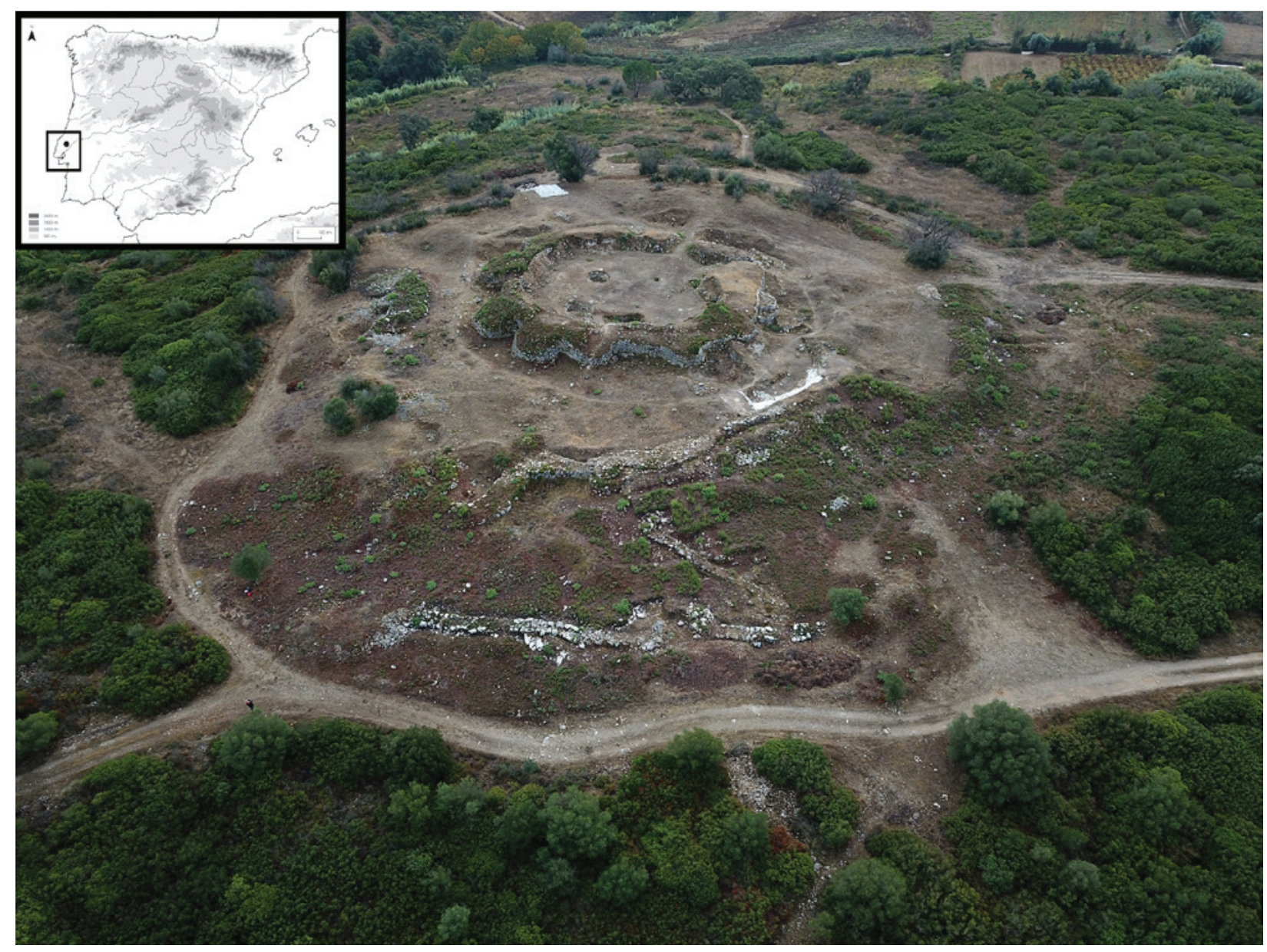

Figura 1 - Vila Nova de São Pedro. 


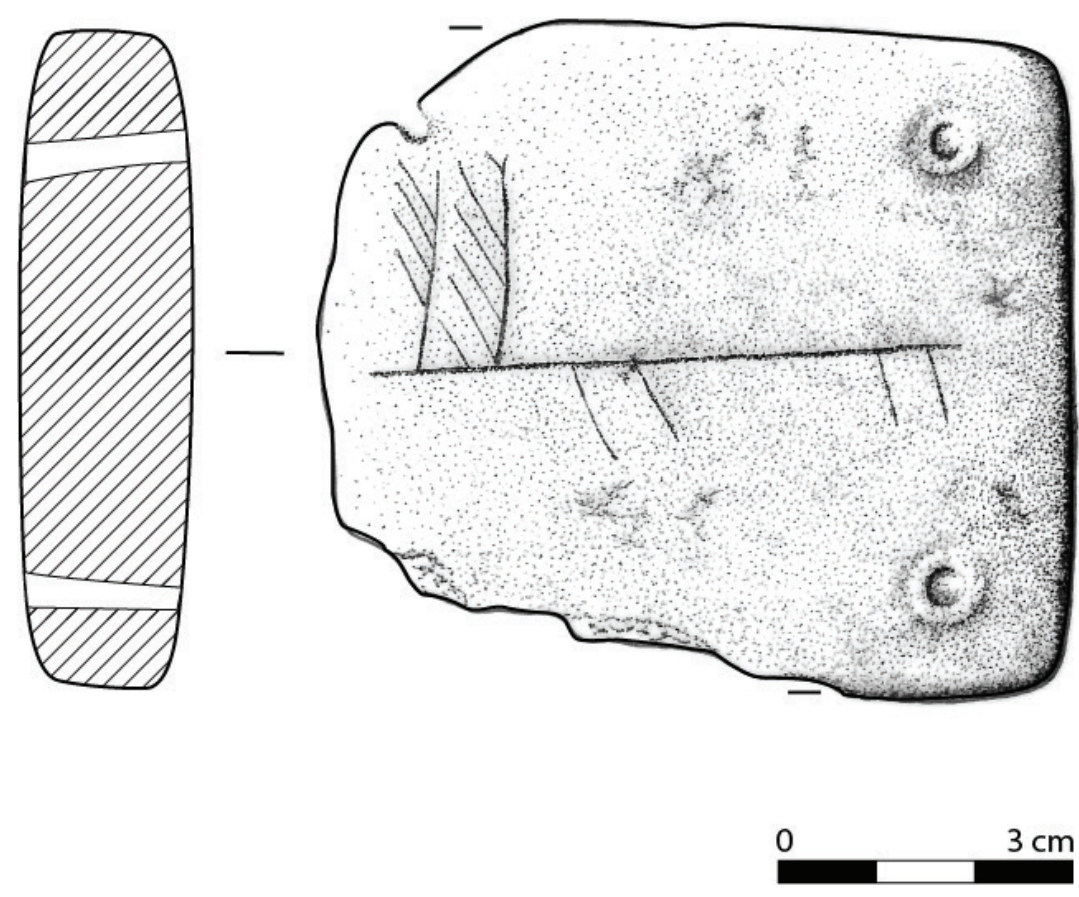

Figura 2 - Placa de tear VNSP3ooo/MAC/236. Autoria: César Neves.
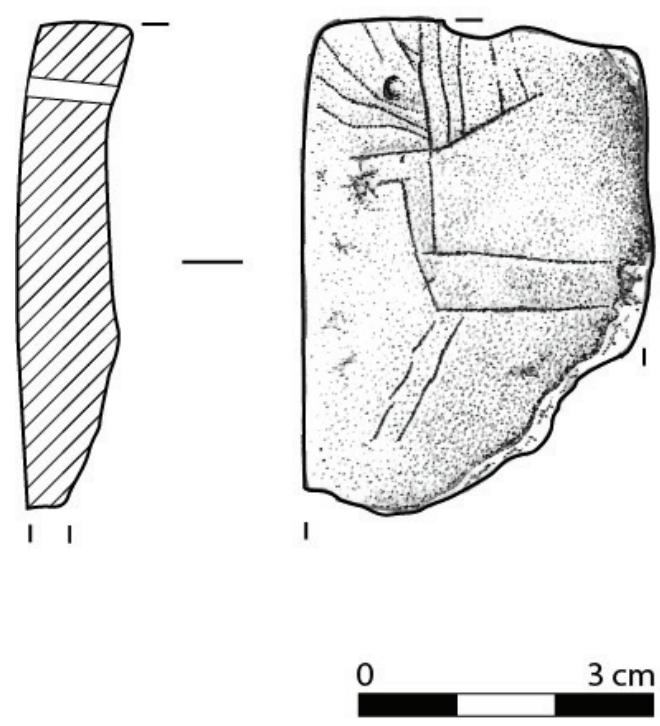

Figura 3 - Placa de tear VNSP3ooo/MAC/269. Autoria: César Neves. 

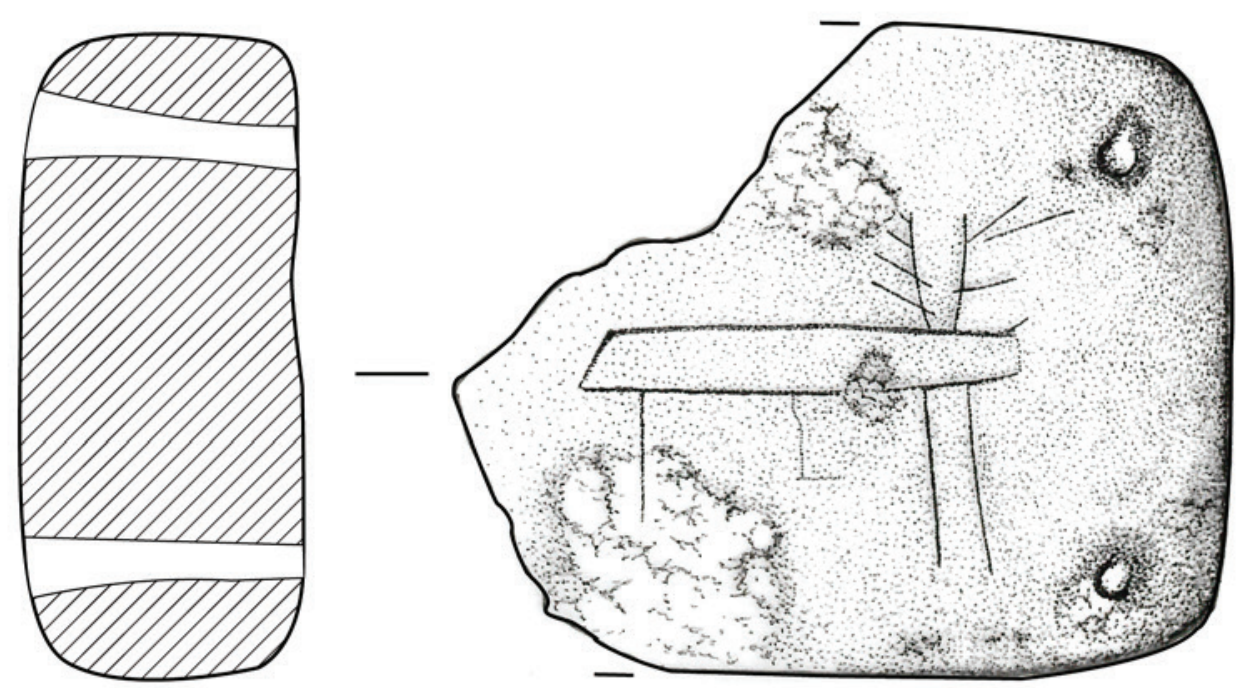

Figura 4 - Placa de tear VNSP3ooo/MAC/305. Autoria: César Neves.
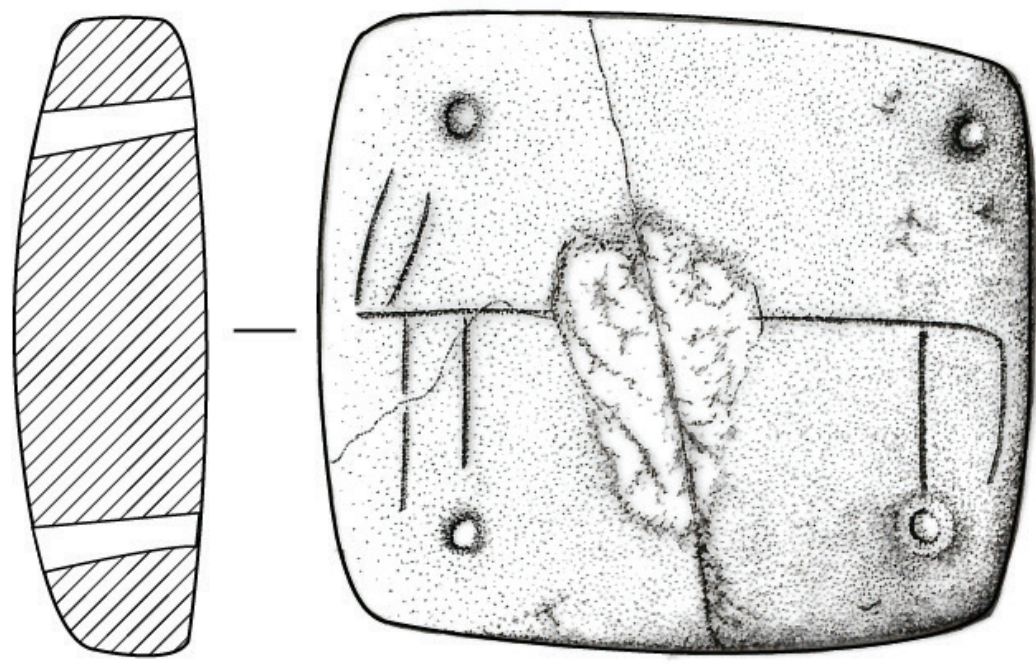

0

$3 \mathrm{~cm}$

Figura 5 - Placa de tear VNSP3ooo/MAC/306. Autoria: César Neves. 


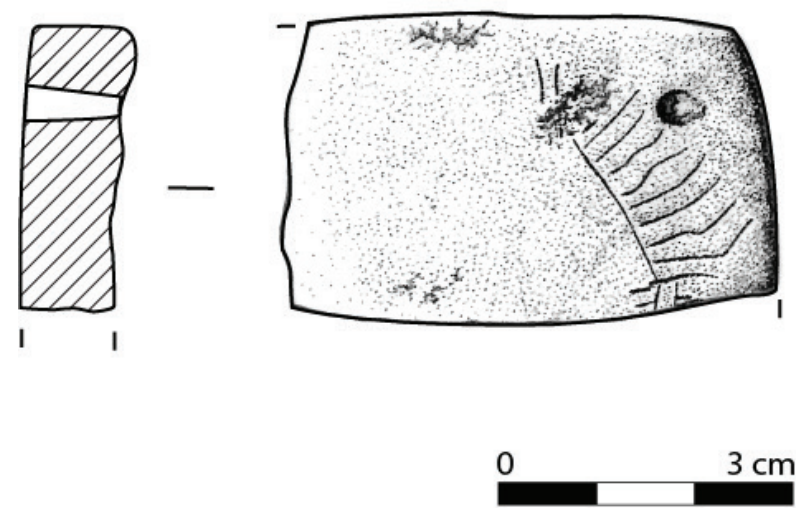

Figura 6 - Placa de tear VNSP3ooo/MAC/345. Autoria: César Neves.
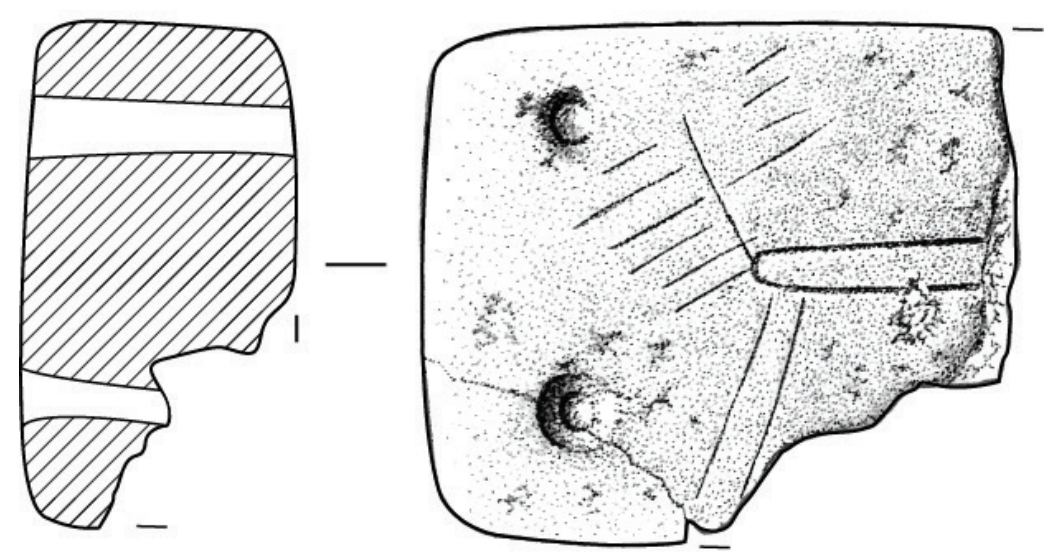

0

$3 \mathrm{~cm}$

Figura 7 - Placa de tear VNSP3ooo/MAC/403. Autoria: César Neves.

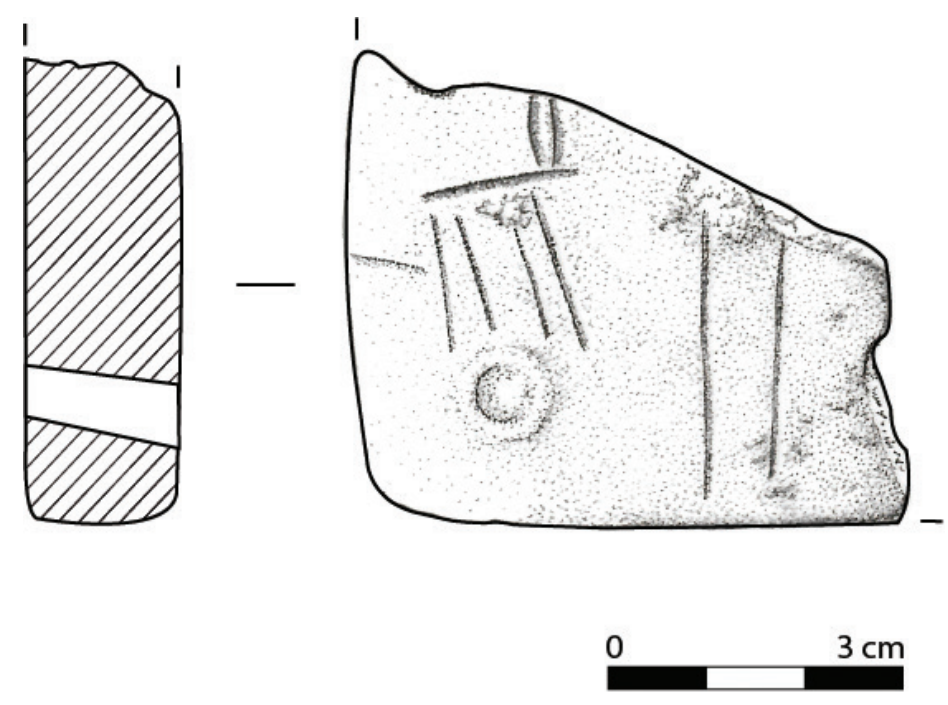

Figura 8 - Placa de tear VNSP3ooo/MAC/409. Autoria: César Neves. 

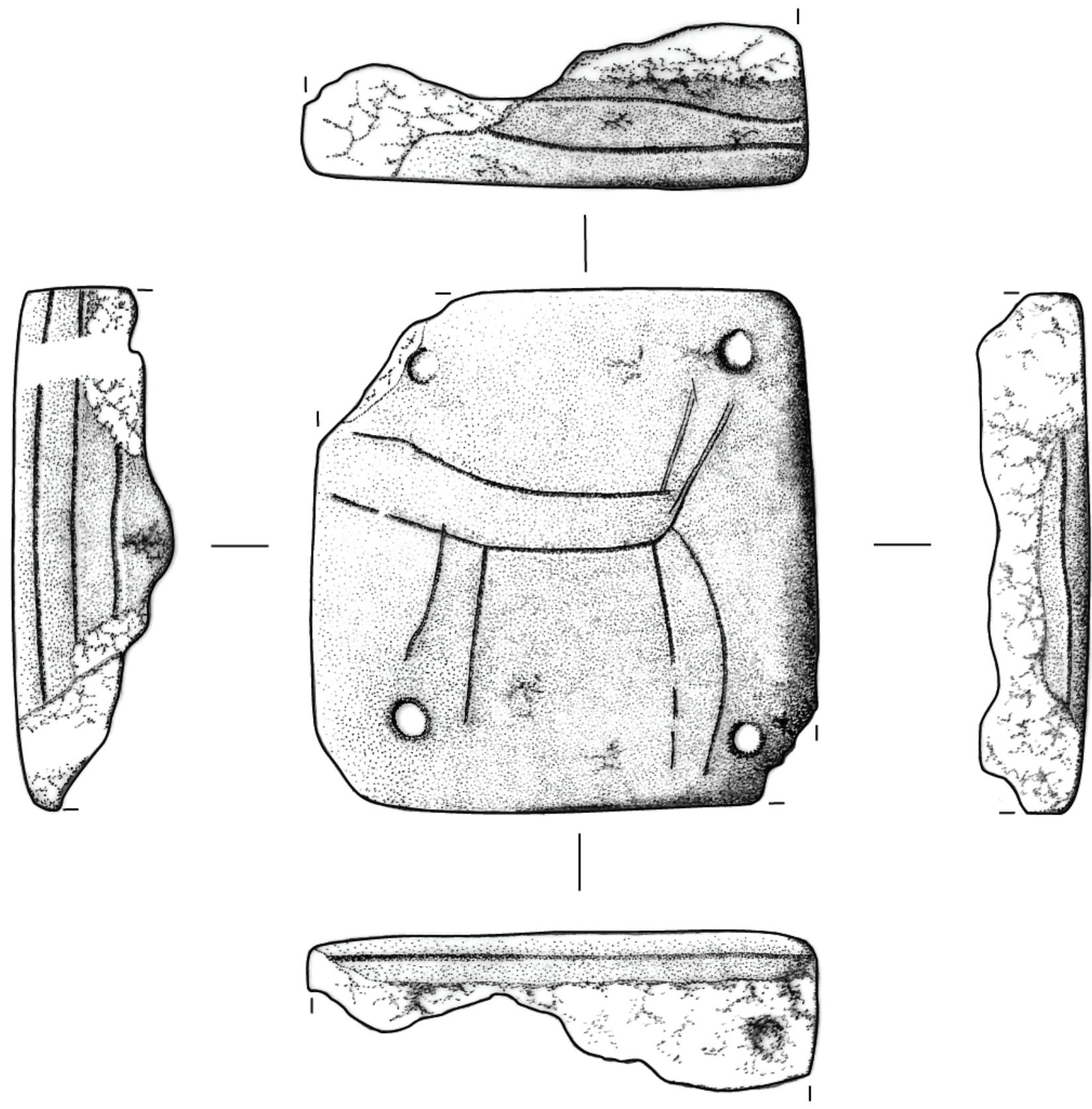

Figura 9 - Placa de tear VNSP3ooo/MAC/446. Autoria: César Neves. 

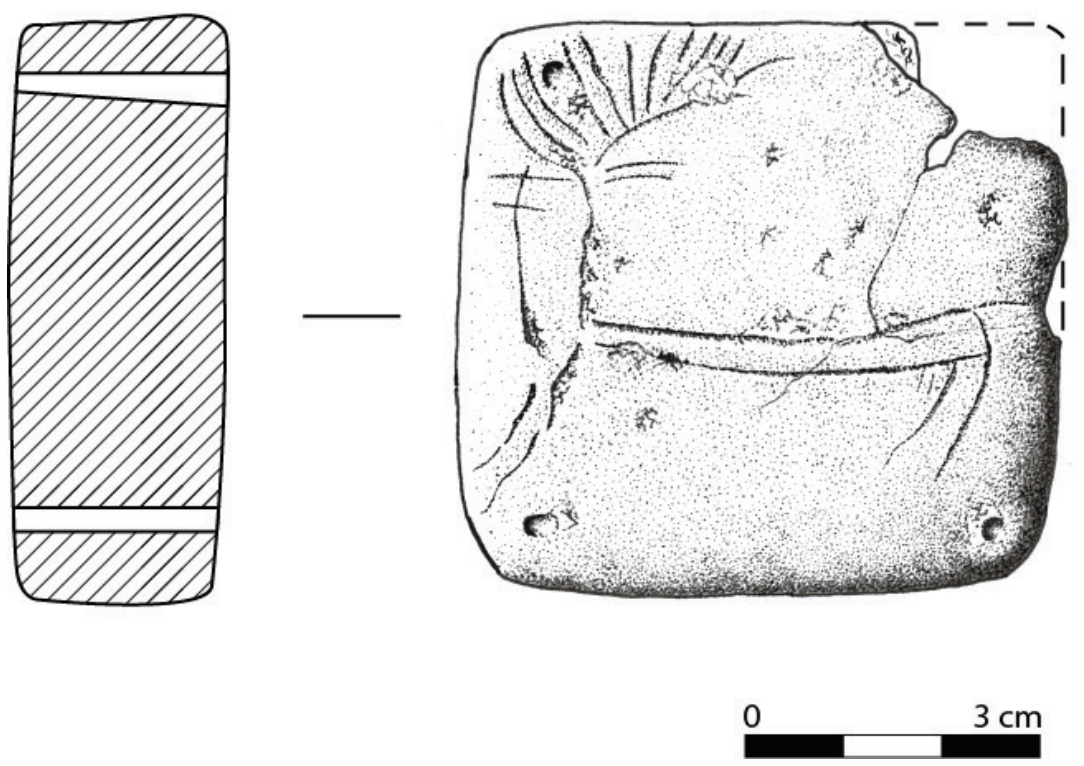

Figura 10 - Placa de tear VNSP3ooo/MAC/475. Autoria: César Neves.
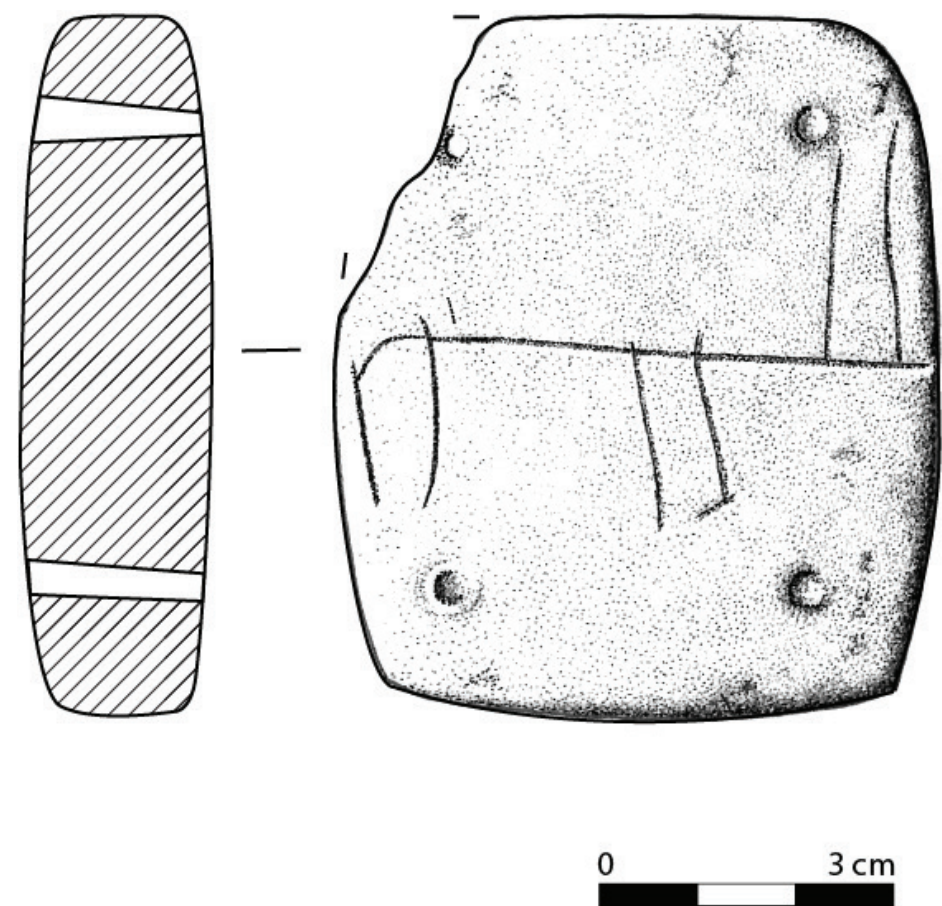

Figura 11 - Placa de tear VNSP3ooo/MAC/49o. Autoria: César Neves. 

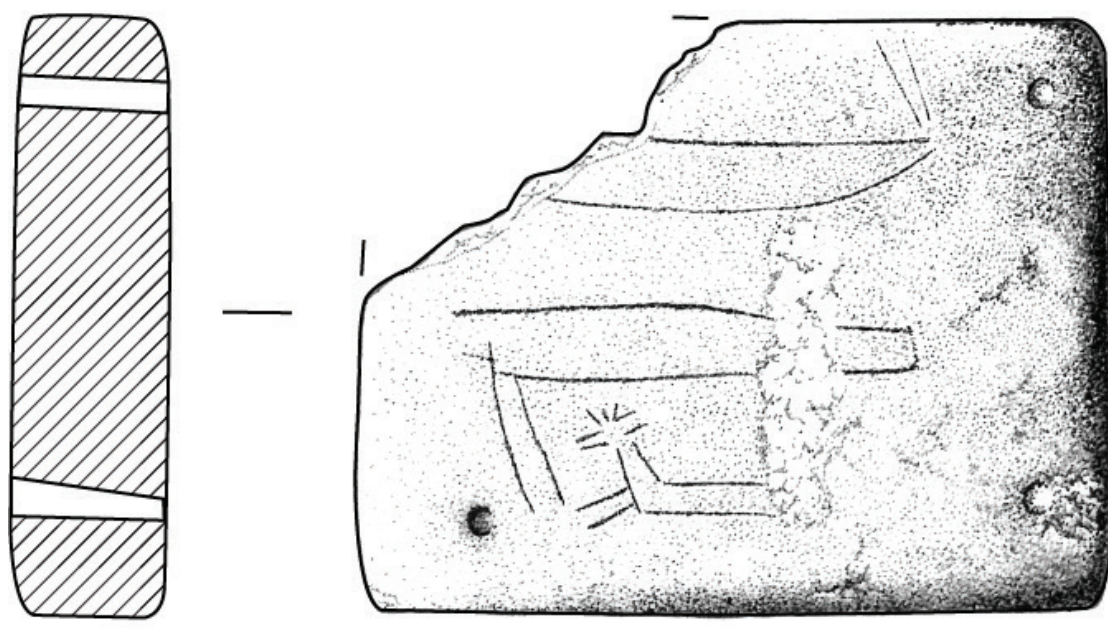

0

$3 \mathrm{~cm}$

Figura 12 - Placa de tear VNSP3ooo/MAC/491. Autoria: César Neves.
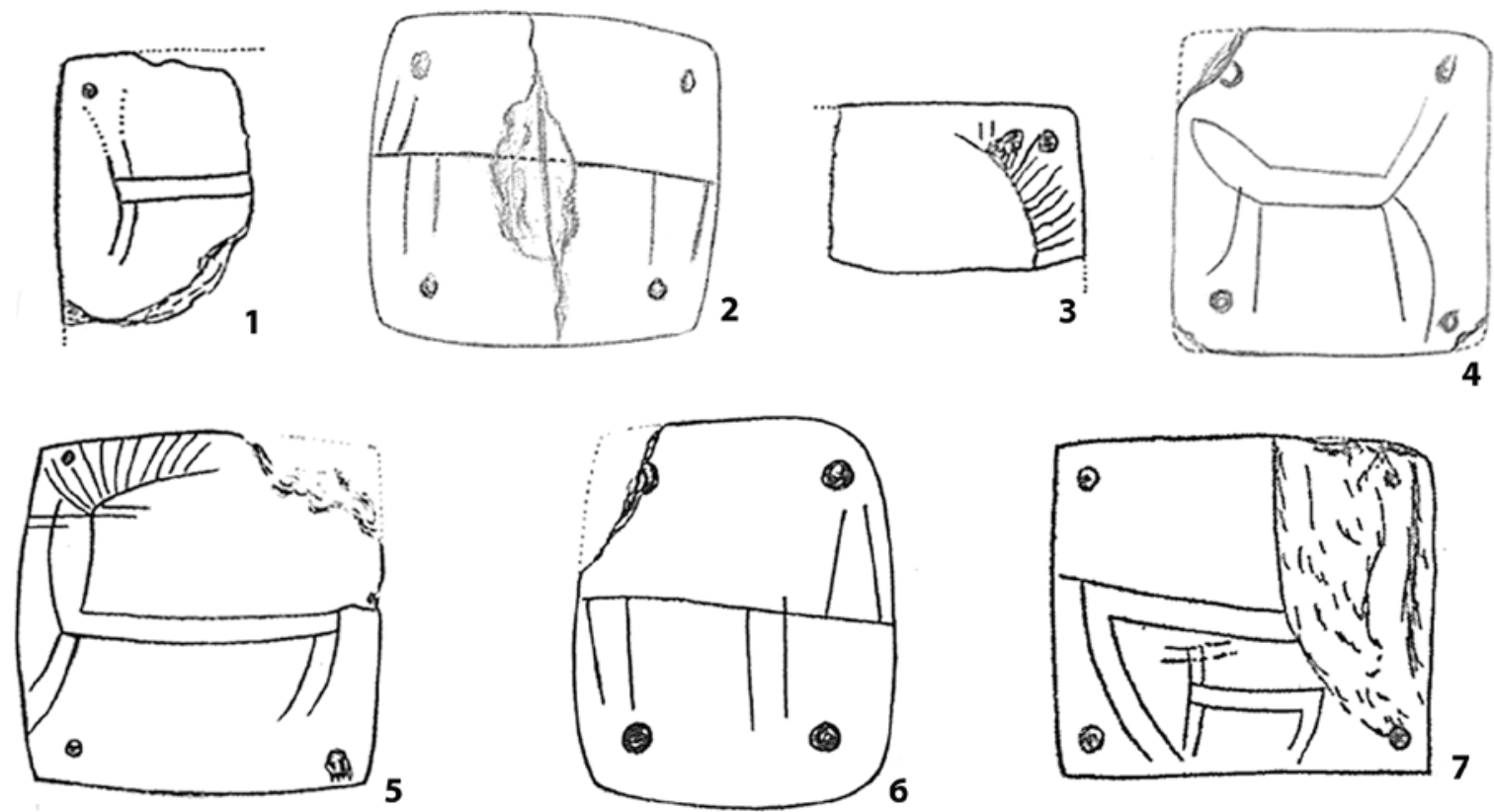

Figura 13 - I - Placa VNSP30oo/MAC/269 - publicada em 1941 (Paço, 1941: 48 - fig. 1 no 7; 2 - placa VNSP30oo/ MAC/306 - publicada em 1942 (Paço e Jalhay, 1942: fig. 25 - nº 2); 3 - placa VNSP3ooo/MAC/345 - publicada em 1941 (Paço, 1941: fig. 1- nº 5); 4- placa VNSP30oo/MAC/446 - publicada em 1942 (Paço e Jalhay, 1942: fig. 25 - nº 1); 5- placa VNSP300o/MAC/475 - publicada em 1939 (Paço e Jalhay, 1939: fig. 25-no 1); 6 - placa VNSP3ooo/MAC/49o publicada em 1939 (Paço e Jalhay, 1939: fig. 25-nº 2); 7 - placa VNSP3ooo/MAC/491 publicada em 1941 (Paço, 1941: fig. 1-nº 4). 


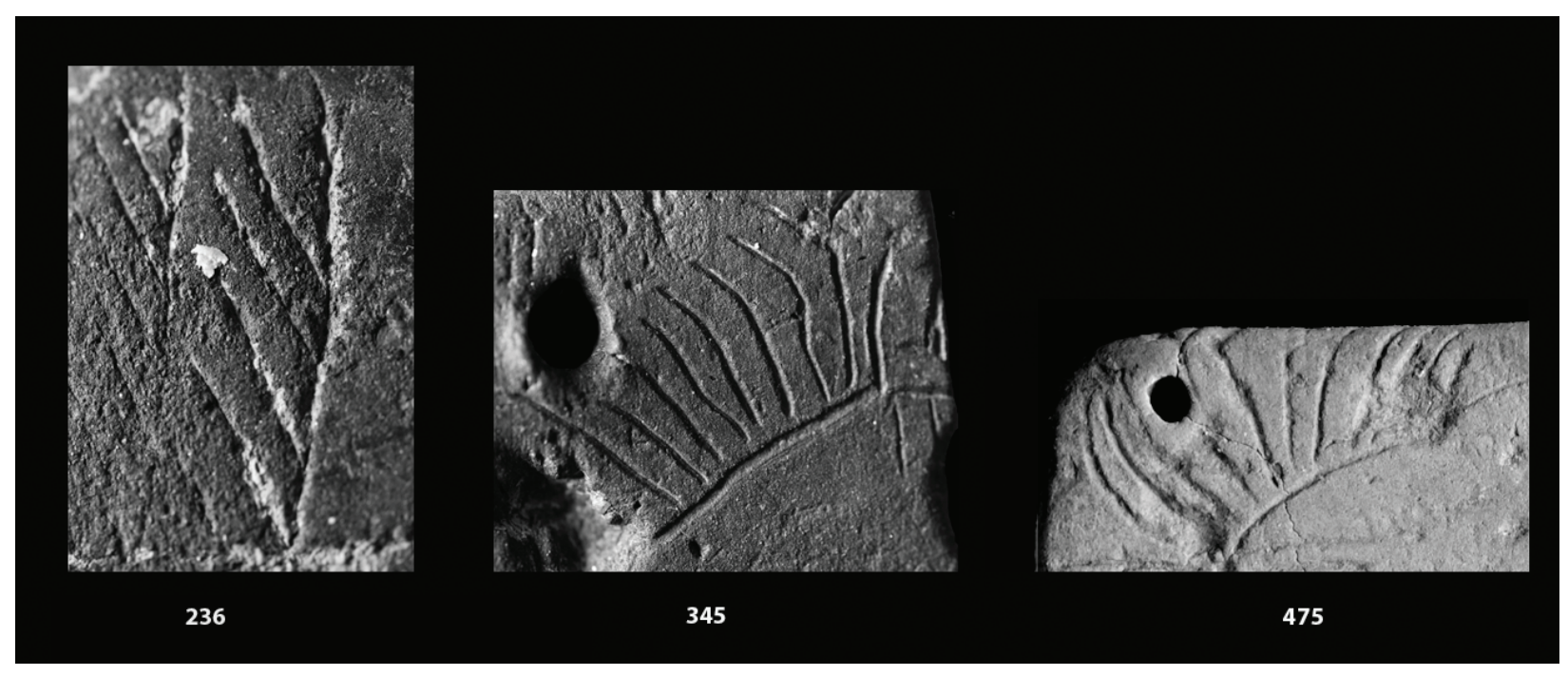

Figura 14 - Pormenor das representações das hastes de veados nas placas VNSP3ooo/MAC/236, VNSP300o/MAC/345 e $\mathrm{VNSP}_{3} \mathrm{OoO} / \mathrm{MAC} / 475$. 



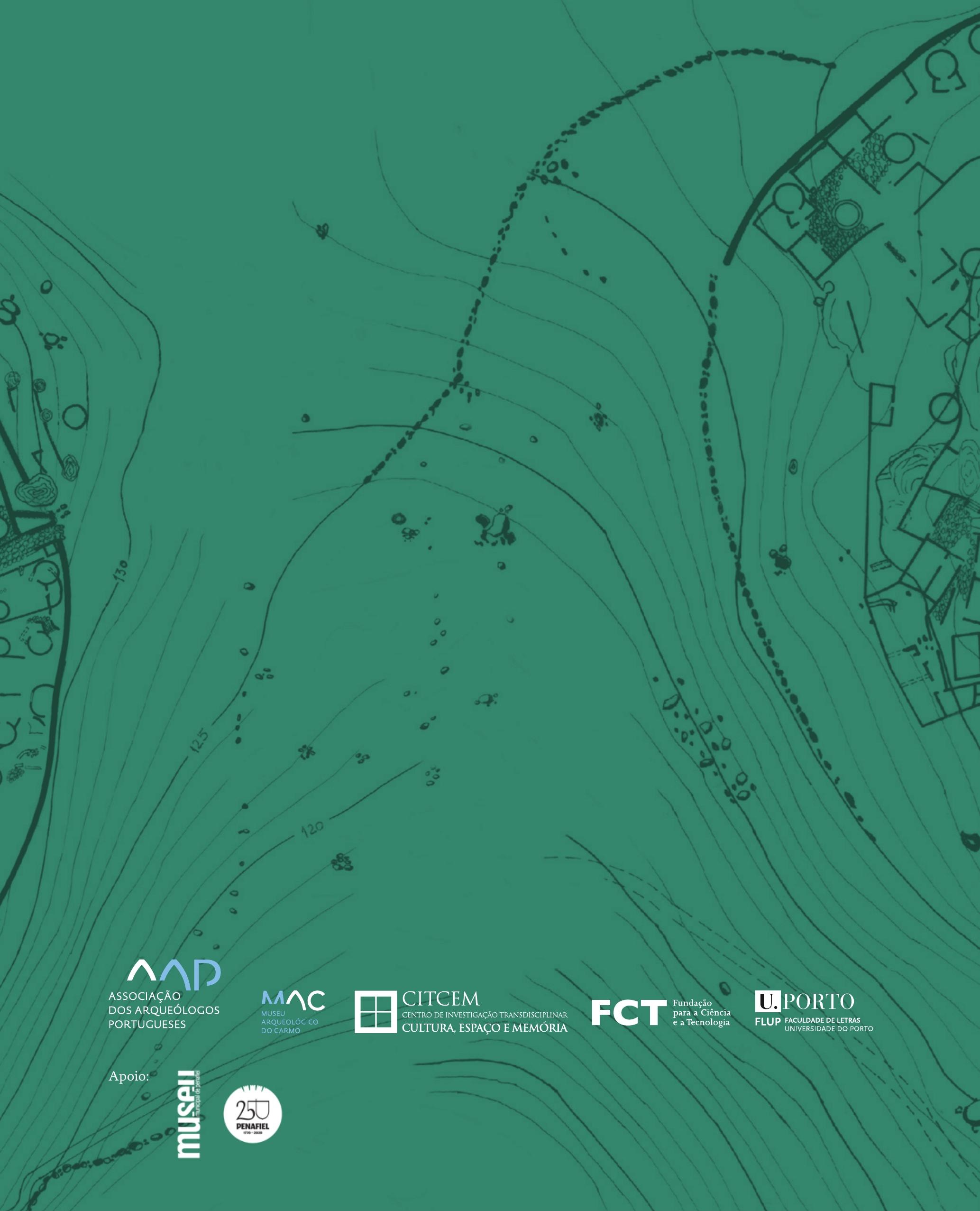

